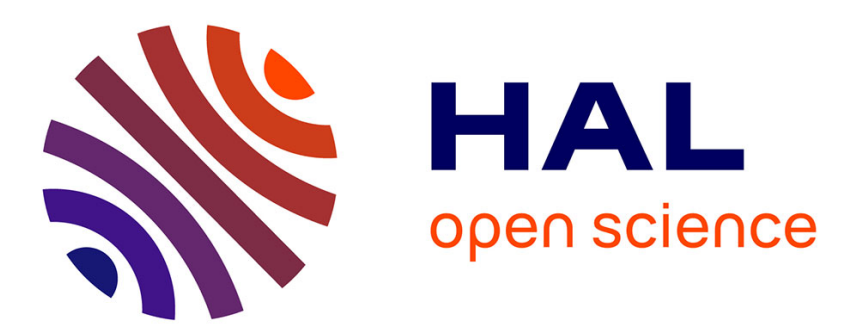

\title{
Timeline of the South Tibet - Himalayan belt: the geochronological record of subduction, collision, and underthrusting from zircon and monazite $\mathrm{U}-\mathrm{Pb}$ ages
} Jean-Pierre Burg, Pierre Bouilhol

\section{- To cite this version:}

Jean-Pierre Burg, Pierre Bouilhol. Timeline of the South Tibet - Himalayan belt: the geochronological record of subduction, collision, and underthrusting from zircon and monazite $\mathrm{U}-\mathrm{Pb}$ ages. Canadian journal of earth sciences, 2019, 56 (12), pp.1318-1332. 10.1139/cjes-2018-0174 . hal-02934696

\author{
HAL Id: hal-02934696 \\ https://hal.science/hal-02934696
}

Submitted on 9 Sep 2020

HAL is a multi-disciplinary open access archive for the deposit and dissemination of scientific research documents, whether they are published or not. The documents may come from teaching and research institutions in France or abroad, or from public or private research centers.
L'archive ouverte pluridisciplinaire HAL, est destinée au dépôt et à la diffusion de documents scientifiques de niveau recherche, publiés ou non, émanant des établissements d'enseignement et de recherche français ou étrangers, des laboratoires publics ou privés. 
1 Timeline of the South-Tibet--Himalayan belt: the geochronological

2 record of subduction, collision, and underthrusting from zircon and

$4 \quad$ Jean-Pierre Burg ${ }^{1}$ and Pierre Bouilhol ${ }^{2}$

51 - ETH Zurich, Department Earth Sciences, Sonneggstrasse 5, 8092 Zurich (Switzerland)

$6 \quad$ jean-pierre.burg@erdw.ethz.ch

72 - CRPG, Université de Lorraine, UMR 7358, 15 rue notre dame des pauvres,Vandoeuvre-lès-

$8 \quad$ Nancy, 54500, France

$9 \quad$ pierre.bouilhol@univ-lorraine.fr

12 Corresponding author: Jean-Pierre Burg

ETH Zurich, Department Earth Sciences, Sonneggstrasse 5, 8092 Zurich (Switzerland)

++ 41446326027

16

Fax: ++ 41446321030

17

jean-pierre.burg@erdw.ethz.ch 


\section{Abstract}

20 The "exact timing" of collision between India and Eurasia is a recurring. Careful dating is critical

21 for all tectonic events. With the example of the South Tibet-Himalaya collision system, a short

22 review of arguments from different approaches suggests that this pursuit is in vain, but that our

23 knowledge is already sufficient to provide an acceptably "precise" timing of the main events. We

24 reviewed $\mathrm{U}-\mathrm{Pb}$ ages of zircons and monazites considering that major tectonic events can produce

25 thermal effects strong enough to be recognized in high-temperature geochronology. This review

26 also shows that precise timing is beyond the precision of the methods and the rock record. General

27 consistency between geologic and thermochronologic records strengthens previous interpretations

28 of the collisional orogenic system. At variance with most tectonic interpretations, we argue that

29 the Tsangpo Suture in South-Tibet results from two merged subduction zones, and that island arcs

30 may be part of the root of the Eurasian paleo-active margin. The two main collisional events

31 closely followed each other at ca. 50 and $40 \mathrm{Ma}$.

33 Key words: Subduction, collision, India, Himalaya, U-Pb thermochronology.

\section{Introduction}

36 The discovery of plate tectonics in the late 1960's allowed renewed interpretation and 37 classification of recent and ancient mountain belts (e.g., Dewey and Bird 1970; Dewey and Burke 38 1973; Dewey et al. 1973). Earth scientists learned that mountain ranges are built along convergent 39 plate margins by successive subduction, occasionally obduction and ultimately continental 40 collision (e.g., Cox and Hart 1986; Kearey et al. 2009; Park 1993), each process overprinted the 41 previous ones. The mega-annual tectonic sequences include magmatic, metamorphic and crustal 
42 shortening-thickening processes (e.g., Condie 1997). Celal Şengör, one of the front-runners in the

43 development of orogeny-plate tectonics relationships, demonstrated the three-dimensional

44 consequences of pre-collisional irregularities on the strain distribution within mountain belts and

45 their forelands (Şengör 1976). Many studies since then have shown that continental fragments,

46 island arcs, and seamounts (as well as post-orogenic faulting and segmentation) introduce

47 complexity in the collision zones (e.g., Şengör et al. 2018). Continental collision and subsequent

48 suturing are therefore "capricious" and "diachronous" records of multiple tectonic events (Dewey

49 1977; Dewey and Kidd 1974). Although this assertion sounds like a late 1970's truism, many

50 authors have disputed the timing of collisional inception in various orogens, especially the Tibet-

51 Himalaya plateau and mountains resulting from the first contact between India and Eurasia (e.g.,

52 Aitchison et al. 2007; Butler 1995; Rowley 1996). In the context of this example, we argue that

53 the recurring controversy is pointless. Different methods yield different lines of evidence and age

54 brackets that refer to different norms and constrain different processes. Combined, these methods

55 yield bulk uncertainties that are, on a geological time scale, sufficiently narrow to satisfy our

56 understanding of the initial collision, although the finest of details have likely forever escaped any

57 geological record.

58 Studies of the South Tibet-Himalaya orogenic system has strongly influenced our general

59 understanding of collisional orogens, though, for the same reason that different methods use

60 distinct criteria, the suite of thermodynamic mechanisms involved in mountain building remains

61 unclear. Here, we first attempt to synthetize the collisional history from geophysical and geological

62 arguments. This review can only refer to a few of the hundreds of articles published on the topic,

63 and confirms that continental subduction followed by intracontinental underthrusting of the Indian

64 continent are the fundamental processes that produced the South-Tibet-Himalaya orogenic belt. 
65 To determine whether the flurry of published geochronological measurements could deliver a more

66 subtle time line to constrain the tectonic evolution of the orogenic system, we compiled high-

67 temperature records from $\mathrm{U}-\mathrm{Pb}$ dating of magmatic and metamorphic zircons and monazites. We

68 avoided methods such as $\mathrm{Rb}-\mathrm{Sr},{ }^{40} \mathrm{Ar} /{ }^{39} \mathrm{Ar}$ and fission tracks as are often linked to exhumation

69 processes that may or may not be due to late tectonic events (e.g., Huntington et al. 2007). The

70 results consistently show that southward-migrating crustal thickening and associated prograde

71 metamorphism are Eocene to Early Miocene in age (ca. 40-20 Ma, e.g., Yin 2006, and references

72 therein) and that out-of-sequence events such as magmatism in the North Himalaya domes and

73 backthrusting along the suture zones remain to be understood.

\section{Setting - Large-scale structure}

75 The $\sim 2500 \mathrm{~km}$ long, $250-350 \mathrm{~km}$ wide South Tibet-Himalaya belt is grossly described as an 76 orogenic wedge formed in sequence in front of and including suture zones that bound the Eurasian 77 backstop. As is apparent in early geological maps (e.g., Argand 1924; Gansser 1964) the belt has 78 a relatively simple, arcuate and cylindrical geometry over most of its length and terminates at both 79 ends in nearly transverse syntaxes named after the main peaks that tower above them: the Namche 80 Barwa (7756 m) in the core of the eastern syntaxis and the Nanga Parbat ( $8138 \mathrm{~m})$ in the western 81 syntaxis in Pakistan (Fig. 1). Southwards-directed and -propagating thrusting has assembled South

82 Tibet and the Himalayas from four main tectonic and lithologic zones that are remarkably 83 consistent all along the length of the mountain belt (Fig. 1). From north to south, i.e., from the 84 structural top to bottom (Fig. 2) these are:

85 1) The Eurasian paleo-active margin, so-called the Transhimalaya or Gangdese Batholith in South Tibet, which continues into the Karakoram Batholith in the western Himalayas. 
2) The Tsangpo Suture Zone delineates the plate boundary along which the Tethyan

88

89

90

91

92

93

94

95

96

97

98

99

100

101

102

103

104

105

106

107

108

109

oceanic lithosphere (ophiolites and deep-sea sediments) that separated India and Eurasia was subducted beneath Tibet. The suture includes tectonic slices of oceanic arcs in South Tibet, which are equivalent to the matured Ladakh and Kohistan Arcs in the western Himalayas (Fig. 1) where the Tsangpo Suture is split into the so-called Shyok Suture to the north and the Indus Suture to the south, between the arcs and India.

3) The Indian continent comprises three sub-units:

- the Tethys Himalaya exposes sediments deposited on the North Indian passive margin and its continental rise, which have been intruded by Eocene and younger granitoids in the North Himalaya domes;

- the High Himalaya mainly composed of ortho- and paragneisses intruded by Miocene leucogranites, is due to intra-continental underthrusting of peninsular India along the basal Main Central Thrust (MCT), and;

- the Lower Himalaya, an imbricate thrust pile of mid-Proterozoic to Cenozoic sequences pertaining to the Indian continental crust.

4) The Sub-Himalaya foredeep, south of the mountain belt.

Each zone is bounded by crustal fault zones (Fig. 2) and has a distinctive stratigraphy and metamorphic-magmatic history. They have been extensively and even repeatedly described with various names in many regional and review publications (e.g., Hodges 2000; Yin and Harrison 2000). Therefore, we will only refer to selected, pertinent information, and detailed descriptions can be found in the abundant literature. We will briefly summarize the tectonic framework of the South-Tibet-Himalaya collision system, discuss the timing of collision, and synthesize existing U$\mathrm{Pb}$ geochronological data to explore how they further constrain important geodynamic events. 


\section{Tectonic history}

111 Magnetic anomalies of the Atlantic and Indian Oceans and paleomagnetic measurements in Asia 112 and India have revealed the relative movement of cratonic India relative to cratonic Asia since the 113 Early Jurassic (e.g., DeMets et al. 2010; Klootwijk et al. 1992; Ricou 1994; Savostin et al. 1986; 114 Torsvik and Cocks 2017).

Tethys Ocean: rifting and ocean spreading

116 A long period of left-lateral, tensional wrenching separated the northern (Laurasia) and southern

117 part (Gondwana) of Pangea (e.g., Muttoni et al. 2003). Lithological, paleontological, geochemical 118 and geochronological evidence from basement rocks and sedimentary cover indicates that India 119 was part of Gondwana. Beginning in the late Paleozoic, rifting progressed westward along the 120 northern Gondwana margin, opening space for the (Neo-)Tethys Ocean (e.g., Stampfli and Borel 121 2002). During the Middle/Late Jurassic and Early Cretaceous, Gondwana split into a western 122 (Africa and South America) and eastern landmass (Australia, Antarctica, India and Madagascar). 123 These two landmasses fragmented further into their respective components during the Cretaceous. 124 India separated from Antarctica and Australia in the Early Cretaceous (ca. 130-135 Ma) and from 125 Madagascar in the Late-Cretaceous (85-90 Ma; Gibbons et al. 2013; Torsvik et al. 2000). Tethys Ocean convergence: subduction to collision

127 Ocean-floor magnetic anomalies offer an external constraint on the convergence history. Although 128 different models yield slightly different histories (e.g., van Hinsbergen et al. 2011), they provide a 129 consistent, first-order image of the relative motion between India and Eurasia.

130 - Cratonic India began to drift northward toward cratonic Asia in the Late Cretaceous (100$13190 \mathrm{Ma}$ ) associated with an anticlockwise rotation of India and representing about $8000 \mathrm{~km}$ 132 of convergence (Patriat and Achache 1984; van Hinsbergen et al. 2012). Plate 
133

134

135

136 reconstructions predict $\sim 7500$ and $8700 \mathrm{~km}$ of convergence at the longitudes of the western and eastern ends of the Himalaya, respectively (e.g. van Hinsbergen et al. 2011), indicating the extent of lithosphere consumed (oceanic Tethys and continental north India). On average, the displacement of India was rapid, reaching $\sim 18 \mathrm{~cm} /$ year around $60 \mathrm{Ma}$ (Patriat and Achache 1984; van Hinsbergen et al. 2012).

- Comparison of paleomagnetic data from South Tibet and apparent polar wander paths for the Indian plate shows that the collision between India and Asia occurred at equatorial latitudes, with progressive suturing since the Paleocene in the westernmost Himalaya (at 67-60 Ma; Beck et al. 1996; Smith et al. 1994) and until the Early Eocene (ca. 50 Ma) in the eastern Himalaya (Rowley 1996).

- India-Eurasia convergence began to decelerate exponentially around $50 \mathrm{Ma}$, usually attributed, along with short-lived changes in drift direction, to the onset of continental subduction and India-Eurasia collision (Patriat and Achache 1984). The displacement rate decreased to $4-5 \mathrm{~cm} /$ year by about $40 \mathrm{Ma}$ and remained nearly steady until further deceleration around $20 \mathrm{Ma}$ (Molnar and Stock 2009). The present-day rate of convergence across the Himalaya is $1.5-2 \mathrm{~cm} /$ year, just under half the total convergence rate (Ader et al. 2012; Bilham et al. 1997).

These 3-episodes of relative motion are generally geodynamically interpreted as follows:

- Subduction of Tethyan oceanic lithosphere. Pulled by an increasingly long subducting slab, the rate of displacement of India was enhanced (e.g., Schellart 2004). Push by the Réunion plume (Cande and Stegman 2011; van Hinsbergen et al. 2011) a positive feedback between two slabs (Jagoutz et al. 2015), or a long-lived convective cell (Sternai et al. 2016) may have contributed to the great velocities. 
- Subduction of the Indian continental lithosphere. Deceleration of the relative convergence

157 is attributed to the buoyancy of the continental lithosphere, which increasingly resisted subduction

158 as the volume of the subducted continental crust increased (e.g., Molnar and Gray 1979).

- Intracontinental shortening. The steady, 4-5 $\mathrm{cm} /$ year average convergence rate is

160 controlled by the deformability of the colliding continental lithospheres and potential pulling by

161 the subducting Indian continental lithosphere (Capitanio et al. 2010). The strength and 162 heterogeneities of the deforming continents control the deformation regime. The onset of strike163 slip-dominated escape tectonics (Tapponnier et al. 1982) may explain the subsidiary $20 \mathrm{Ma}$ 164 slowing of convergence. Paleomagnetic data (Klootwijk et al. 1986) and differential convergence 165 rates between the western and eastern edges of India (Molnar and Stock 2009; van Hinsbergen et 166 al. 2011) indicate ongoing anticlockwise rotational underthrusting of India in the Himalaya.

\section{Subduction to collision}

168 The Kohistan and Ladakh Arc terranes in the NW Himalaya indicate that intra-oceanic subduction 169 was well established by ca. 135 Ma (e.g., Burg 2011; Rolland et al. 2000; Thakur and Misra 1984), 170 and may even have started earlier, around 155 Ma (Jagoutz et al. 2018). These arcs, active 171 throughout the Cretaceous, are remnants of a chain of island arcs that extended eastward, possibly 172 for the entire length of the India-Asia suture zone (Burg 2007; Hébert et al. 2012). Such remnants 173 are also found within the strike-slip-dominated lateral boundaries of the Indian Plate e.g., the 174 Muslim Bagh ophiolites along the Chaman Fault (Kakar et al. 1971) and the Naga Hills ophiolites 175 in the Indo-Burman range (Dey et al. 2018). To the north of these volcanic arcs, the back-arc 176 oceanic lithosphere was subducting below the Eurasian active margin (i.e., the Transhimalaya and 177 Karakoram terranes; Fig. 1), producing the abundantly dated calc-alkaline magmatism (e.g. Searle 178 et al. 2010; Wen et al. 2008). A two-subduction system was therefore consuming the large Tethys 
179 Ocean at least until ca. $95 \mathrm{Ma}$ (Burg 2007, 2011), and may have ceased upon the 90-85 Ma plate

180 reorganization and the separation of India from Madagascar. "Himalayan" blueschists exhumed at

181 that time (Anczkiewicz et al. 2000; Honegger et al. 1989) may also represent this global event.

182 Granodioritic and volcanoclastic pebbles in Aptian-Albian conglomerates of the forearc of the

183 Transhimalaya indicate that the Asian active margin was already deeply eroded at that time,

184 suggesting an elevated Andean-type orogen since the Cretaceous (An et al. 2014; Burg and Chen

185 1984; Einsele et al. 1994). Besides magmatic and geochemical evidence, we know very little about

186 Early Cretaceous subduction. Recent tectonic reconstructions suggest that the oceanic arc was then

187 at equatorial latitudes (Hafkenscheid et al. 2006). Positive P wave seismic velocity anomalies in

188 the mantle beneath South India may represent sunken slabs of this intra-oceanic subduction (Van

189 der Voo et al. 1999; Zahirovic et al. 2012).

190 Magmatic products and their geochemistry are further evidence for Late Cretaceous to Eocene 191 subduction (e.g., Bouilhol et al. 2013; Ji et al. 2009), and plate reconstructions agree on the 192 northward drift of India and coeval consumption of several thousand kilometres of oceanic 193 lithosphere (e.g., Besse and Courtillot 1991; Schettino and Scotese 2005; Stampfli and Borel 2002; 194 Torsvik and Cocks 2017). The 80 to 70 Ma hiatus in dated subduction-related magmatism of the 195 Transhimalaya, Andean-type margin may reflect a change in slab behaviour, be it cessation of the 196 subduction that closed the back -arc basin or roll-back or breakoff (Ji et al. 2009; Wen et al. 2008).

197 Age of collision initiation

$198 \quad$ What defines collision initiation?

199 The initiation of the India-Eurasia collision should refer to the first contact between Indian and 200 Eurasian continental crusts after disappearance of the Tethyan oceanic lithosphere. The age of this 
201 event is still disputed between disciplines. In this discussion, it is worth recalling key results used

202 to set the framework in which collision took place.

203 Paleomagnetic and oceanic magnetic anomalies

204 Perhaps one of the most influential attempts to date the collision between India and Eurasia has

205 been the study of India's motion with respect to the more stable Eurasian plate using seafloor 206 magnetic anomalies (Molnar and Tapponnier 1975). They revealed a sharp decrease in 207 convergence rate in the Eocene, which was interpreted as "the most likely time for initial contact 208 between India and Eurasia”. Higher resolution data and paleomagnetic interpretations confirmed 209 this rapid deceleration and revealed accompanying erratic shifts of India's motion between 210 anomalies 22 and 18 (50-42 Ma; Patriat and Achache 1984). These rate and directional changes 211 were attributed to a fluctuating balance between pulling and buoyancy forces during subduction 212 of the irregular northern continental margin of India. Later reconstructions of India relative to 213 Eurasia (e.g., Besse et al. 1984; Copley et al. 2010; Dewey et al. 1989; Klootwijk et al. 1992; van 214 Hinsbergen et al. 2011) agree that oceanic subduction continued until ca. $50 \mathrm{Ma}$ (anomaly 22) and 215 was followed by increased resistance to subduction until ca. $44 \mathrm{Ma}$ (anomaly 20). This period of 216 "soft" collision changed to "hard" collision when buoyant forces of the underthrust continental 217 crust opposed further subduction, beginning the ongoing continental shortening and coeval 218 thickening in both India and Eurasia (Chemenda et al. 2000). Whether separate accretionary events 219 and crustal deformation episodes, including the Himalayan orogeny, may be correlated with (or 220 responsible for) episodic pulses in sea floor spreading at the trailing edges of India (e.g., 221 Merkouriev and DeMets 2006; Molnar and Stock 2009; White and Lister 2012) remains debatable 222 because the uncertainties associated with each reconstruction are not resolved. 


\section{$223 \quad$ Stratigraphic and sedimentary criteria}

224 In general, oceanic closure due to continental collision is correlated with a change from marine to 225 continental sedimentation and terrestrial fauna trespassing the ophiolitic suture.

226 The oldest reported faunal exchange between India and Eurasia is that of amphibians between 227 western India and Afghanistan (Jaeger et al. 1989), suggesting that continental bridges between 228 the two continental blocks at the western end of the Himalayas existed as early as the Cretaceous229 Paleocene boundary (around $65 \mathrm{Ma}$ ). The ca. $54 \mathrm{Ma}$ exchange of terrestrial fauna between India 230 and Asia is similarly consistent with early continental pathways between the two continental 231 masses (Clementz et al. 2011; Kapur et al. 2017). These faunal migrations have been linked to the 232 initiation of the collision. However, the western margin of the Indian plate was a transform 233 boundary along which promontories may have formed early connections without physical 234 consequences on the India-Asia collision in South Tibet. The first arrival on the Indian plate of 235 clastic grains attributed to the active margin of Eurasia is dated at about $52 \mathrm{Ma}$ (Najman et al. 236 2010; Zhuang et al. 2015). Yet, detritus reaching India may have been far-travelled if the trench 237 had been filled at that time, and a western provenance cannot be excluded. Furthermore, Early 238 Cretaceous (ca. 140-115 Ma) extension-related dykes, sills, and magmatic stocks intruded Tethyan 239 sediments (Chen et al. 2018; Zhu et al. 2009), and Cretaceous clastic zircon grains found in Eocene 240 sediments may indicate that such intrusions were already eroded at the time of deposition.

241 Paleostratigraphic evidence dates the development of a flexural bulge in the western (Ladakh) 242 outer margin of India to the Paleocene-Eocene boundary, ca. 55 Ma (Garzanti et al. 1987). This

243 bulge implies that northwestern continental India had entered the trench and begun subducting at 244 that time. Marine, shelf sedimentation on the northern continental margin of India continued until 245 the Eocene in South Tibet (Mu et al. 1973), and more precisely into the Priabonian (38-34 Ma, 
246 Jian et al. 2016). This age is almost $10 \mathrm{~m} . \mathrm{y}$. younger than the final marine deposits preserved in

247 other Himalayan regions (short review in Jian et al. 2016) with a possible tendency of slightly

248 older ages in the western regions that would support the west to east collisional progression during

249 the Eocene (Rowley 1996) due to anticlockwise rotation of India (Patriat and Achache 1984). In

250 South Tibet, an abrupt change in lithology and clastic content around $60 \mathrm{Ma}$ is attributed to the

251 earliest contact between Asia and continental India, which was followed by southward migration

252 of the Indian continental bulge (DeCelles et al. 2014).

253 The so-called Xigaze Basin, an important element of the suture, is a forearc basin with Early 254 Cretaceous deep marine radiolarites deposited atop ophiolites (Allègre et al. 1984); overlying 255 turbidites followed by Late Cretaceous shelf and fluvio-deltaic marine strata witness the filling of 256 the basin with no sign of early collision up to ca. 65 Ma. (An et al. 2014; Einsele et al. 1994; Hu 257 et al. 2016). Adjacent to the forearc sequences, non-marine Upper Oligocene-Lower Miocene 258 (Kailas) conglomerate-rich sequences unconformably cover the Eurasian magmatic arc. They are 259 ascribed to an extensional basin conjecturally related to southward rollback of the Indian 260 continental lithosphere, ca. 30 m.y. after the initiation of collision (DeCelles et al. 2011). 261 Reconciling the various sedimentary settings, the transition from marine to continental facies must 262 have occurred during the Eocene.

\section{Tectonic and deformation criteria}

264 Discussing the time of collisional initiation assumes uninterrupted Indian continental crust entering 265 in contact with the continuous Eurasian lithosphere. However, such an assumption is hardly 266 tenable when considering the Tethyan paleogeography. Several realms come in consideration.

267 The northern continental margin of India may well have been an extended margin with several 268 continental ribbons and fragments separated from the main continent. Such "allochthons" are 
269 common in distal parts of modern margins (e.g., Brune et al. 2014; Mohn et al. 2015). They may

270 have been the basement of the distinctive Permian reef limestones found as exotic blocks in the

271 South Tibet olistostrome (Jin et al. 2015) and other Tethyan regions from Turkey to the Himalaya

272 (Marcoux and Baud 1996; Stampfli et al. 1991). This possibility questions the nature, extent and 273 thickness of the missing lithosphere discussed as "Greater India" (e.g., Ali and Aitchinson 2005;

274 van Hinsbergen et al. 2012)

275 The Tethys Ocean may have contained seamounts (Dai et al. 2012) and a chain of island arcs

276 forming the eastern correlatives of the Kohistan-Ladakh arc (Burg 2007; Hébert et al. 2012).

277 Related back-arc and forearc basins had unknown widths, possibly variable along strike.

278 These lithospheric irregularities have been accreted to the southern margin of Eurasia. Each 279 accretionary event would qualify as collision initiation and may be apparent as the reported erratic 280 behaviour of India (e.g., White and Lister 2012).

$281 \quad$ Metamorphic criteria

282 Eclogite facies and ultra-high-pressure (UHP) metamorphic assemblages of mafic rocks belonging 283 to continental India have been dated to constrain the collisional timing and processes. These few 284 occurrences in the western Himalaya indicate that the leading edge of the Indian crust was 285 subducted down to $\sim 100 \mathrm{~km}$ (metamorphic pressure $>3 \mathrm{GPa}$ ) at 55-45 Ma (de Sigoyer et al. 2000; 286 Guillot et al. 2008; Kaneko et al. 2003; Leech et al. 2005). A simple trigonometric calculation 287 shows that with an average Indian plate velocity of $4.5 \mathrm{~cm} /$ year (Besse et al. 1984; Klootwijk et 288 al. 1992; Molnar and Stock 2009) and $\mathrm{a} \sim 20^{\circ}$ subduction angle consistent with the mantle wind 289 (Ficini et al. 2017), the given age would date the arrival of continental India in the trench at about 29070 Ma. The subduction angle may have been steeper (ca. 40) later (Guillot et al. 2007); any 291 estimate assumes large uncertainties. Rapid exhumation of these rocks followed a retrograde path 
292 through amphibolite conditions between 45 and 35 Ma to near-surface cooling at ca. 25-5 Ma (e.g.,

293 Wilke et al. 2001).

294 Granulitized eclogites in the High Himalaya (Burg et al. 1987; Grujic et al. 2011; Lombardo et al.

295 2016) record pressures $>1.5 \mathrm{GPa}\left(50-60 \mathrm{~km}\right.$ depth) before near isothermal $\left(\sim 700^{\circ} \mathrm{C}\right)$

296 decompression to < $0.4 \mathrm{GPa}$. These eclogites have been variously dated to 40-23 Ma with re297 equilibrated in the granulite facies during the Middle Miocene (15-10 Ma; Corrie et al. 2010; Cottle 298 et al. 2009; Kellett et al. 2014).

\section{Geochemical and isotopic criteria}

300 The Transhimalayan magmatic belt formed the active continental margin of Eurasia during the 301 north-dipping Tethys subduction (e.g., Allègre et al. 1984). Whole rock Sr and Nd isotope ratios 302 and zircon Hf isotopic compositions indicate a dominantly juvenile mantle source of the mostly I303 type granitoids (Harris et al. 1988). Negative $\varepsilon H f$ and $\varepsilon N d$ values in related volcanic rocks indicate 304 the Gondwana affinity of the pre-batholith, Archean-Proterozoic continental basement (Zhu et al. 305 2011). Compiling zircon U/Pb ages (Fig. 3) shows that the continental margin of Asia (Gangdese 306 and Karakoram Batholiths, Fig. 1) was magmatically active from the Jurassic (ca. 190 Ma, Chu et 307 al. 2006) to the Miocene (up to ca 9 Ma, Zhang et al. 2014). Jurassic magmatism was possibly 308 related to south-dipping subduction of the Bangong-Nujiang oceanic lithosphere to the north of 309 this Gondwana-derived continental block (e.g., Zhu et al. 2011), but alternatively may be related 310 to early north-dipping subduction of the Tethys Ocean (e.g., Kang et al. 2014). Cretaceous- Eocene 311 calc-alkaline plutons (forming the batholith) are admittedly attributed to this Tethys subduction 312 (Allègre et al. 1984). Peaks in the zircon age distribution (Fig. 3) should be cautiously interpreted 313 in terms of large magmatic volumes or flare-ups because they often denote the number of 314 geochronological data measured on similar samples or plutons, as near Lhassa in the Gangdese 
315 (e.g., Wen et al. 2008) and near the Karakoram Fault (e.g., Ravikant et al. 2009). Nonetheless, the

316 existing data suggest quiescence between Cretaceous (120-80 Ma) and Paleogene (70-45 Ma)

317 stages (Wen et al. 2008). Even accounting for the time of magma ascent, the Eocene ages have

318 been taken as evidence for cessation of subduction and disappearance of oceanic lithosphere

319 between India and Asia ca. $45 \mathrm{Ma}$ (Allègre et al. 1984). Changes in $\varepsilon H f$ values of magmatic zircons

320 are ascribed to slab breakoff ca. $52 \mathrm{Ma}$ (Zhu et al. 2011). However, owing to bias in the data set,

321 and because the southern Eurasian margin developed on a Gondwanian basement, changes in

322 isotopic compositions of the Transhimalaya Batholith cannot be definitely ascribed to changing

323 subduction dynamics and collision (Bouilhol et al. 2013). Younger (30-9 Ma), protracted

324 magmatic episodes are ascribed to lithospheric phenomena after closure of the Tethys Ocean (e.g.,

325 Zhang et al. 2014).

326 In contrast to the Transhimalaya Batholith, the Kohistan-Ladakh plutonic rocks developed from 327 juvenile magmatic activity in oceanic lithosphere since at least ca. $135 \mathrm{Ma}$ and until ca. $40 \mathrm{Ma}$ 328 (Fig. 3). In these oceanic arcs, compositional changes may be interpreted in terms of subduction 329 dynamics. In-situ U-Pb geochronology, zircon $\mathrm{Hf}$ isotopic compositions, and whole-rock $\mathrm{Nd}$ and 330 Sr isotopic data indicate that the Kohistan-Ladakh island arcs were accreted to India around 50 331 Ma and that the India/arc assemblage collided with Eurasia around $40 \mathrm{Ma}$ (Bouilhol et al. 2013; 332 Garzanti et al. 1987).

\section{Collision - orogenic wedge}

\section{Sutures}

335 Multiple collisions are evident where the Kohistan and Ladakh arcs are preserved between two 336 sutures (as adopted in Fig. 4). In South Tibet, only the Tsangpo Suture (Fig. 1) is delineated by a 337 set of dismembered ophiolites representing the Tethys Ocean, fore-, inter-, and back arcs (Hébert 
338 et al. 2012), and small remnants of oceanic arcs (Aitchison et al. 2000). This diversity implies that

339 the Tsangpo Suture zone encompasses and overprints several subduction and collision events

340 (Burg 2007). After some dispute as to whether the island arcs were accreted to Eurasia during the

341 Cretaceous (e.g., Coward et al. 1982; Frank et al. 1977; Petterson and Windley 1985) or only after

342 accretion to India in the Eocene (e.g., Bard 1983; Klootwijk et al. 1979), geochronological and

343 isotopic studies on plutonic rocks of the Kohistan-Ladakh arcs linked changes in the magmatic

344 source regions to arc/India collision at ca. $50 \mathrm{Ma}$ followed by Eurasia/arc collision at ca. $40 \mathrm{Ma}$

345 (Bouilhol et al. 2013). Such data do not preclude a more complex history in which several thousand

346 kilometres of Tethys Ocean and its various (perhaps unrelated along-strike) oceanic plateaus,

347 forearcs, arcs and back arcs were reduced to a narrow suture a few metres to few kilometres wide

348 and several thousand kilometres long in geological maps. Overprinting by late faulting such as

349 Miocene backthrusting bounding the southern Transhimalaya (Burg and Chen 1984; Yin and

350 Harrison 2000) and the Karakoram Batholith (Searle et al. 1988) may have buried the accreted

351 units, rendering the successive discrete collisions impossible to decipher. Such buried units may

352 provide an explanation for "bodies" of seismic reflectors observed along the suture zone (Guo et

353 al. 2017; Makovsky et al. 1999). Overall, the timeline suggests a general northward migration of

354 collisional events until hard, total closure ca. $40 \mathrm{Ma}$, when the never-subducted Xigaze forearc of

355 the Transhimalaya was folded (Burg and Chen 1984; Yin and Harrison 2000).

\section{$356 \quad$ Greater India}

357 Greater India, i.e., the pre-collisional extent of India's northern continental crust, is difficult to 358 outline because of large uncertainties in the locations and shapes of pre-collisional margins 359 destroyed by subduction and collisional deformation. However, the extent of Greater India is a 360 critical question since it directly addresses how and where collision began to affect the continent 
361 and how subsequent convergence between India and Asia may have been accommodated. The

362 proposed extent of Greater India varies by up to several thousand kilometres according to different

363 authors (review of Ali and Aitchinson 2005). Several tectonic reconstructions fitting the possible

364 northern boundary of Greater India with the margins of Australia suggest around $800 \mathrm{~km}$ of

365 continental crust to the north of the Himalayan front (e.g., Zahirovic et al. 2012) possibly preceded

366 by up to $\sim 2000 \mathrm{~km}$ of Indian oceanic lithosphere (e.g., van Hinsbergen et al. 2012). Such a wide

367 passive margin may have been strongly extended (thinned), and would have been easily subducted

368 without a noticeable effect on the plate motion. With such freedom, we have no reason to depart

369 from most of the aforementioned interpretations. We can accept a set of pre-50 Ma events related

370 to various small collisions with oceanic plateaus, arcs, and continental allochthons of the thinned

371 passive margin (Greater India) while slab pull remained dominant and contributed to the very high

372 convergence rate. At about $50 \mathrm{Ma}$, the main Indian continental crust entered subduction along with

373 island arcs, an event sufficient to drastically slow Indian plate motion. Since buoyancy forces were

374 subordinate until that time, the subduction system (soft collision) was essentially ablative (non-

375 accreting senso von Huene and Scholl 1991). Hard collision, when buoyancy forces became an

376 important and caused accreting orogeny, began at that time.

\section{Slab break-off}

378 Detachment of the oceanic slab from the continental Indian lithosphere has been considered as an 379 efficient mechanism to interrupt pull (van Hunen and Allen 2011), hence slowing the incoming 380 Indian plate between 50 and $40 \mathrm{Ma}$ and changing the collisional dynamics from soft to hard 381 collision (Chemenda et al. 2000). Several slab break-off events during the India-Eurasia 382 convergence have been inferred on the basis of secular changes in magmatic arc composition, in 383 particular the ca. 50 Ma magmatic flare-up of shoshonitic magma in the Transhimalaya (Lee et al. 
384 2009) and termination of arc-related magmatism shortly thereafter, around $45 \mathrm{Ma}$ (Chung et al.

385 2005). As previously discussed, relating compositional changes in Transhimalaya plutonic rocks

386 to subduction dynamics is uncertain since crustal thickness may affect melt composition,

387 especially in continental magmatic arcs (Freeburn et al. 2017). Slab break-off interpretations were

388 motivated by at least two low-velocity anomalies in the lower mantle, which may be attributed to 389 stagnant slabs of Tethyan oceanic lithosphere beneath India (Replumaz et al. 2010; Van der Voo 390 et al. 1999). Analogue (Chemenda et al. 2000) and numerical (Magni et al. 2017) models relevant

391 to the India-Asia collision suggest that the inferred Eocene loss of oceanic lithosphere byslab 392 break-off during continental subduction could trigger exhumation of UHP metamorphic rocks of 393 the Indian plate, which in turn underplating the overriding Asian plate.

\section{Accreting collision}

395 The three sub-units of the exposed northern margin of India (from north to south the Tethys, High 396 and Lower Himalaya; Figs. 1 and 2) represent the south-directed collisional accretionary system 397 that developed in sequence at the expenses of "Greater" India. Some authors have suggested that 398 collision may have started earlier in the west and subsequently propagated eastward along the 399 Himalaya (e.g., Klootwijk et al. 1986; Rowley 1996). Such a diachronous, eastward migrating 400 collision is consistent with faster convergence rates in the eastern corner of India than of the 401 western corner (e.g., Molnar and Stock 2009; van Hinsbergen et al. 2012).

402 In the western Himalayas, the direct footwall of the suture includes gneisses and UHP eclogites 403 dated at 55-50 Ma (de Sigoyer et al. 2000; Kaneko et al. 2003). In South Tibet, 40 Ma high-pressure 404 gneisses are in a similar structural position (Laskowski et al. 2016). These rocks demonstrate that 405 continental material was buried to about $100 \mathrm{~km}$ in the Eocene. As already discussed, these high406 pressure metamorphic ages reflect the arrival of continental, Indian material in the trench around 
$40770 \mathrm{Ma}$, assuming an average Indian plate velocity of $4.5 \mathrm{~cm} /$ year and a $\sim 20^{\circ}$ subduction angle are

408 assumed. Yet, this information does not stipulate whether India was subducting beneath the

409 Kohistan-Ladakh and laterally equivalent island arcs or beneath the Karakoram-Transhimalaya

410 margins of Eurasia.

411 In South Tibet, isoclinally folded turbidites unconformably covered by the latest-Cretaceous-

412 Paleocene olistostrome represent the oldest thrust system adjacent to the suture; they are 413 interpreted to be part of an accretionary wedge (Burg and Chen 1984). Provenance analysis of 414 clastic zircons in sandstone blocks suggests both Cretaceous and Late Paleocene-Early Eocene 415 deposition (An et al. 2017). Cretaceous deposition occurred during an essentially non-accreting 416 subduction, which we interpret to be the trench in front of the island arcs, later amalgamated with 417 the Paleocene/Eocene wedge in front of the Transhimalaya forearc (Fig. 4). These rock units were 418 later redeformed in the Late Eocene, along with the north- and south subdomains of the Tethys 419 Himalaya (Burg and Chen 1984). Since the Xigaze forearc was folded in the same time interval, 420 hard collision was well in progress during the Late Eocene.

421 Further south, the High Himalayan gneiss consists of a north-dipping pile of tectono-stratigraphic 422 units that, according to isotopic data, are late Proterozoic to early Paleozoic rocks of the upper 423 continental crust of India (e.g., Parrish and Hodges 1996; Whittington et al. 1999). Mesozoic 424 sediments, originally situated on the northern margin of India, lay locally on this monotonous 425 gneiss sheet that varies in thickness from 2 to $10 \mathrm{~km}$ (e.g., Le Fort 1975). This thrust sheet is a 426 deeply rooted crustal slice (Nelson et al. 1996) whose bottom is the ductile MCT. The gneiss and 427 migmatites bear evidence of multiple deformation and recrystallisation events ascribed to 428 Himalayan southward shearing, with the dominant fabric defined by amphibolite facies 429 assemblages (e.g., Brunel 1986). The High Himalayan gneiss was intruded by Miocene 
430 leucogranites contemporaneous with normal faulting (Burg et al. 1984a). The north-dipping

431 extensional system known as South Tibetan Detachment (Burchfiel et al. 1992) is the tectonic

432 contact separating the High Himalaya from the Tethyan sedimentary sequences along the mountain

433 belt. The following analysis of thermochronological data focuses on whether those data allow 434 refining of the tectonic narrative.

\section{Thermochronological record in Indian rock units}

436 To better constrain the high-temperature timing of the different orogenic zones, we have compiled $437 \mathrm{U}-\mathrm{Pb}$ data of zircons from magmatic rocks in domes of the Tethys Himalaya (Fig. 5), and U-Pb 438 zircon ages and $\mathrm{U}-\mathrm{Th} / \mathrm{Pb}$ monazite ages of the High Himalayan gneiss (Fig. 6). Recent advances

439 in linking monazite $\mathrm{U}-\mathrm{Th} / \mathrm{Pb}$ ages with their microstructural setting and rare earth element 440 concentrations allow distinction between prograde and retrograde grains (e.g., Pyle and Spear 441 2003). We have selected published $\mathrm{U}-\mathrm{Th} / \mathrm{Pb}$ data from transects across the High Himalayan gneiss, 442 carefully identifying "prograde" high-Y from "retrograde" low-Y monazite ages. In general these 443 thermochronological data are consistent with the overall southward propagation of magmatic and 444 metamorphic events.

\section{Tethys Himalaya}

446 In South Tibet, a string of domes (collectively called the North Himalayan Belt) stretches about $44750 \mathrm{~km}$ south of, and nearly parallel to the Tsangpo Suture, within the Tethyan Himalaya (Fig. 1). 448 They are culminations of a long, orogen-parallel antiform attributed to ramp-thrusting and 449 subsequent extension, diapirism, or a combination of these mechanisms (Lee et al. 2000). These 450 domes expose Proterozoic (up to ca. 1800 Ma inherited zircon cores, e.g., Aoya et al. 2005; Liao 451 et al. 2008) and Early Paleozoic (Lee et al. 2000; Schärer et al. 1986) basement orthogneiss 452 intruded by small-volume granitoids (e.g., Aikman et al. 2008). Our zircon age compilation shows 
453 rather continuous melt production with five main pulses occurring almost rhythmically every $\sim 10$ 454 m.y., from 45 to $7 \mathrm{Ma}$ (Fig. 5, references in supplementary material). The gneissic-granitic domes 455 core concentric greenschist to amphibolite facies metamorphic zones (Burg et al. 1984b; Lee et al. 456 2004) on which ${ }^{40} \mathrm{Ar}-{ }^{39} \mathrm{Ar}$ dating yields cooling ages of micas at ca. $10 \mathrm{Ma}$ and fission track apatite 457 ages of ca. $5 \mathrm{Ma}$ (Lee et al. 2000).

458 These metamorphic domes provide evidence of burial down to $0.7-0.9 \mathrm{GPa}$ for $600-700^{\circ} \mathrm{C}$ at 50 $45945 \mathrm{Ma}$ (e.g., Ding et al. 2016; Lee et al. 2004). Zircon populations separated from the orthogneiss 460 and the granitoids show a wide range of inheritance, with a dominant proportion of Ordovician 461 grains among younger grains spanning the Mesozoic (Fig. 5, references in supplementary 462 material). The cores of those inherited Ordovician grains indicate that Indian orthogneisses were 463 important melt sources, whereas the Mesozoic grains indicate that Tethyan lithologies contributed 464 to the melts from which Eocene and Miocene granitoids were generated. The bulk-rock isotopic 465 compositions of these granitoids show negative initial $\mathrm{Nd}$ istopic ratios $\left(\varepsilon \mathrm{Nd}_{\mathrm{i}} \sim-14\right)$ and high 466 radiogenic $\mathrm{Sr}\left({ }^{87} \mathrm{Sr} /{ }^{86} \mathrm{Sr}>0.715\right)$, consistent with such crustal source components (e.g., Gao and 467 Zeng 2014; Zeng et al. 2011). However, the ca. 45 Ma intrusions in the North Himalayan domes 468 and surrounding Tethyan sediments are mantle-derived (ENdi 6, Ji et al. 2016a).

469 High Himalaya

470 The High Himalaya gneiss pile (Fig. 6) shows a multi-stage metamorphic history with 471 metamorphic grade increasing structurally upward (e.g., Kohn 2014). The most prominent stages 472 are:

473 1) Remnants of eclogite-facies metamorphism ( $\geq 1.5 \mathrm{GPa})$ within the gneiss show a wide age range between $40 \mathrm{Ma}$ (Kellett et al. 2014; Laskowski et al. 2016) and as young as $15 \mathrm{Ma}$ for those closest to the MCT (Corrie et al. 2010), which is at odds with the older ages of the 
476

477

478

479

480

481

482

483

484

485

486

487

488

489

490

491

492

493

494

495

496

497

498

surrounding gneisses and migmatites. These eclogites were recrystallized during Miocene granulite facies metamorphism at $>750^{\circ} \mathrm{C}$ and $\sim 1 \mathrm{GPa}$ (Groppo et al. 2007; Kellett et al. 2014).

2) Barrovian-type metamorphism: The north-dipping gneiss pile above the MCT shows a northward, upward-decreasing metamorphic sequence from $\sim 550^{\circ} \mathrm{C}$ near the $\mathrm{MCT}$ to $700^{\circ} \mathrm{C}$ about $5 \mathrm{~km}$ above in the overlying migmatites, with pressures consistent with a lithostatic gradient (e.g., Hodges et al. 1988; Pêcher 1989). This metamorphic event started its prograde path at 45-35 Ma, likely during burial of the Precambrian protolith following continental collision. Metamorphism may have started earlier (50-45 Ma, Smith et al. 1994) in the western than in the eastern Himalaya.

Conversely, the metamorphic sequence is inverted in the MCT zone, with a continuous downward decrease in metamorphic grade and temperature. The sillimanite-bearing migmatites and gneiss occur above a narrow zone of kyanite-bearing schists, in turn above successively staurolite, garnet, biotite, and lower grade metamorphic zones (Fig. 6). Within this MCT zone, synmetamorphic shearing evolved at 20-25 Ma. Zircon and monazite ages are younger (20-10 Ma, e.g., Mottram et al. 2015) than in the upper pile. Burial of the footwall rocks ceased at ca. $10 \mathrm{Ma}$ but further reactivation lasted into Late-Miocene (5-8 Ma) times (5-8 Ma, e.g., Oliver et al. 1995).

3) The dominant metamorphic event occurred under higher temperature and lower pressure conditions $\left(650-800^{\circ} \mathrm{C}\right.$ and $\left.0.4-0.7 \mathrm{GPa}\right)$ during the Miocene (30-18 Ma, Clarke et al. 2016), obliterating most of evidence of the earlier, higher pressure event.

4) Low-pressure and -temperature conditions are mostly recorded in the contact zones of the 25-12 Ma tourmaline-muscovite-garnet leucogranites that define a belt of small plutons, 
499

500

501

502

503

504

505

506

507

508

509

510

511

512

513

514

515

516

$517 \sim 700^{\circ} \mathrm{C}$ (Parrish 1990). Like the prograde ages, the retrograde ages are younger structurally 518 downward towards the MCT (Fig. 6).

stoks and dyke networks (e.g., Cottle et al. 2015). Their shear fabrics give evidence for normal faulting and rapid denudation in the upper levels of the High Himalaya (Burchfiel et al. 1992; Burg et al. 1984a). Residual and/or peritectic andalusite and sillimanite, and biotite inclusions in cordierite indicate that melts formed by dehydration melting of muscovite at $660-700{ }^{\circ} \mathrm{C}$ and $\sim 0.7 \mathrm{GPa}$ (Patiño Douce and Harris 1998). Further exhumation later in the Miocene (20-15 Ma) occurred at lower, sillimanite grade pressure and temperature (500$700^{\circ} \mathrm{C}$ and $\left.0.2-0.4 \mathrm{GPa}\right)$.

\section{Monazite ages}

Monazite rare earth element concentrations allow distinction between prograde and retrograde growth. More than half of the 668 selected $\mathrm{U}-\mathrm{Th} / \mathrm{Pb}$ ages from monazites of the High Himalayan gneiss pile are prograde (Fig. 7). Their age distribution is asymmetric: prograde monazites increase in occurrence from 40 to about $20 \mathrm{Ma}$ before sharply decreasing from 20 to $16 \mathrm{Ma}$ (Fig. 7). A precursory small peak around $36 \mathrm{Ma}$ represents the upper part of the gneiss pile, whereas prograde monazite ages are younger structurally downward towards the MCT (Fig. 6, Kohn 2014). Peaks exceeding the distribution envelope at 17 and 20 Ma correspond to over-represented samples that we were not able to objectively filter from the dataset.

Retrograde monazite ages also show an asymmetric distribution: retrograde monazites increase in occurrence from 30 to $16 \mathrm{Ma}$ and quickly decrease by $13 \mathrm{Ma}$ (Fig. 7), the time of cooling below

\section{Zircon ages}

520 Only a few U-Pb zircon ages between 50 and $40 \mathrm{Ma}$ have been reported from the High Himalayan 521 gneiss pile (Fig. 7). Apart from those, the histogram envelope of zircon ages increases from 38 to 
$52225 \mathrm{Ma}$ in a similar asymmetric distribution as the prograde monazites, peaks between 25 and 20

$523 \mathrm{Ma}$, then sharply decreases between 20 and $15 \mathrm{Ma}$. The abundant 25-15 Ma age population

524 includes the time of crystallization of most High Himalaya leucogranites (Fig. 7, references in

525 supplementary material). The peak departing from this general trend at 32 Ma possibly represents

526 zircon dates from outcrops that were the subjects of several publications, though insufficiently

527 reported sampling locations prevented us from filtering those data.

\section{Discussion}

\section{Continental subduction of Indian continental margin}

530 The Indian continental basement is exposed in three settings: (1) UHP gneisses, (2) the North 531 Himalayan Domes and (3) the High Himalaya. In addition, many Indian-derived inherited zircon 532 are found in the Kohistan-Ladakh and Transhimalayan plutonic rocks (Bouilhol et al. 2013; Chu 533 et al. 2011). These zircons, along with the Hf isotopic constraints, indicate that the Indian plate 534 was underthrust beneath these arc regions during the Eocene ( $\mathrm{Xu}$ et al. 2010). The metamorphic 535 age of the northernmost exposed UHP part of India is up to $55 \mathrm{Ma}$, and metamorphism and melting 536 occurred at 50-40 Ma in the North Himalayan Domes and 40-20 Ma in the High Himalaya (Fig. 537 7). These ages are therefore consistent with the structurally inferred history of in-sequence, 538 southward propagation of the South Tibet-Himalaya orogenic system.

\section{North Himalayan Domes}

540 Alkaline gabbros of mantle origin are present in the North Himalayan Domes and are

541 contemporaneous with ca. 45 Ma crustal granitoids. These mantle melts are interpreted to represent 542 slab break-off ( $\mathrm{Ji}$ et al. 2016b), though $45 \mathrm{Ma}$ corresponds to the age ascribed to the UHP 543 metamorphism in the NW Himalaya and to retrogressed eclogites in the High Himalaya. Coeval 544 mantle and crustal melting events are difficult to interpret in a continuous and uniform Indian 
545 lithosphere, as is postulated to underlie the Tethyan sedimentary sequences. Discontinuities may

546 be inherited from the structure of the passive margin of India. It is worth noting that the North

547 Himalaya basement rocks crop out below Late Paleozoic series (e.g., Burg et al. 1984b; Lee et al.

548 2004) whereas Cambrian-Ordovician and younger Paleozoic sequences remain on the northern

549 flank of the High Himalaya pile (e.g., Burg and Chen 1984; Liu and Einsele 1994). If the

550 stratigraphy is correct, the South Tibetan Detachment cannot be a unique fault zone from the High

551 Himalaya to the domes (Lee et al. 2000) because it would ramp up-section in the direction of

552 movement. Instead, different stratigraphic layers may have been deposited at different times on

553 low and high extensional blocks of the North Indian passive margin. Such structural discontinuities

554 would have been prone to compressional reactivation during the Cenozoic.

555 Along with the metamorphic record in the domes, mantellic and crustal magmas suggest burial of 556 the Indian crust during Eocene subduction and possible decompression melting of the underlying 557 mantle when exhumation began. This interpretation questions the importance of the thrusts 558 mapped to the south of the domes (e.g., Burg and Chen 1984), whose throw may have been 559 underestimated. In any case, the geographical and age distributions in these domes do not support 560 a double-sided, centripetal slab detachment (Webb et al. 2017) or southward migrating 561 delamination of the Indian lithosphere (DeCelles et al. 2011). Should we include the UHP 562 occurrences in the same group of basement outcrops as the North Himalayan Domes, they may all 563 represent segments of blocks of the North Indian margin (Fig. 4) that underwent parallel but 564 separate subduction histories before upward extrusion within the Tethyan realm.

\section{High Himalaya}

566 Early metamorphic/magmatic events in the High Himalaya Indian crust are indicated by the ca. 567 35Ma zircons in High Himalaya leucogranites (Fig. 5, e.g., Zhang et al. 2012), about 10 m.y. later 
568 than early events in the North Himalayan Domes (Aikman et al. 2008). Consistent monazite and

569 zircon ages suggest that thrusting deformation began in the Late Eocene.

570 The age distributions of zircons and prograde and retrograde monazites bracket the time of High

571 Himalayan metamorphism. Prograde and retrograde monazite ages (Fig. 7) coincide with the ages

572 of most High Himalaya leucogranites (e.g., Montomoli et al. 2015), suggesting that the

573 metamorphic climax and main melting event of the High Himalaya gneiss pile occurred around 20

574 Ma, as concluded in a number of previous studies (e.g., Harris et al. 2004; Singh 2018; Weinberg

575 2016). The system then cooled rapidly within ca. 5 m.y., with downward strain localization and

576 southward propagation of the increasingly brittle deformation accompanying thrusting of the High

577 Himalaya on its foreland. The fact that older ages are statistically found in the structurally upper

578 part of the gneiss pile and that prograde and retrograde ages are young downward is symptomatic

579 of in-sequence Himalayan thrusting (e.g., Kohn 2014). Prograde ages in the footwall of the basal

580 MCT and retrograde ages in the hanging wall (Kohn 2014) are consistent with post-12 Ma 581 transport of the High Himalaya metamorphic sequence over the underlying Lower Himalaya units.

582 High-Himalaya-North Himalayan Domes conundrum

583 These thermochronological arguments support the idea that the orogenic wedge developed grossly

584 in sequence. The variety of magmatic and metamorphic ages reveals a varied tectonometamorphic 585 history along the belt.

586 A part of the conundrum is that there is no plutonic crystallization age between 10 and $25 \mathrm{Ma}$ in 587 the North Himalayan Domes, though this spans the time of leucogranite intrusions on the top of 588 the High Himalaya. Yet, there is "out-of-sequence" leucogranitic magmatism as young as ca. 9 589 Ma in the domes (Fig 5). If there are 45 Ma crustal and mantle-derived intrusions in the domes, 590 there is no other evidence for melting at this time in the High Himalaya other than melt inclusions 
591 in kyanite-bearing gneiss dated at about 42Ma (Carosi et al. 2015) and few zircon ages. These

592 provide the sole witness of a possible temporal link between an early phase of metamorphism and

593 melting in the High Himalaya and the domes. Such thermochronological data advocate for thermal

594 decoupling between the two orogenic settings, which has already been suggested from $\mathrm{Ar} / \mathrm{Ar}$ 595 dating (Coleman and Hodges 1998). These data also indicate that early melting of the Indian crust 596 under high-pressure conditions may have contributed to the Eocene intrusions found in the North 597 Himalayan Dome.

598 A working hypothesis would be, again, to consider the North Himalyan domes as outliers of rifted 599 Indian margin (Fig. 4) that were accreted within the Tethyan sediments during the early stages (55$60040 \mathrm{Ma}$ ) of continental subduction. The High Himalaya formed by in-sequence thrusting after about $60130 \mathrm{Ma}$. Underthrusting of India allowed stacking and underplating of continental material via 602 duplexing and extrusion to form the accretionary wedge as we know it today.

\section{Conclusions}

604 The record from different disciplines is sufficient to confirm the general framework of collisional 605 tectonics in the South Tibet-Himalaya orogenic system.

606 The collision of India and Eurasia is marked by two main suture zones bounding island arcs in the 607 western Himalaya. Tectonic shreds of island arcs along the Tsangpo Suture in South Tibet suggest 608 similar protracted collisional events. Sometime in the early Paleocene, northern India, and possibly 609 continental slivers ahead of it, collided with the chain of intra-oceanic island arcs at near-equatorial 610 latitudes. The missing parts of the arcs and their back-arc lithosphere have been subducted beneath 611 the Transhimalaya Batholith and the active continental margin of Asia, and the (Xigaze) forearc 612 was gently folded only in Eocene times. This tectonic arrangement requires protracted collision 613 between 55 and $40 \mathrm{Ma}$. This further implies that the Tsangpo Suture should be considered as a 
614 double suture where remnants of the Tethys Ocean, the oceanic arc system with its back arc, and

615 the fore-arc of Eurasia have been subducted and/or imbricated in the orogen. These remnants may

616 contribute to the present-day thickness of the Transhimalaya.

617 Zircon and monazite ages track the generally in-sequence, southward progression of the orogenic

618 deformations at the expense of the Indian continent. The early collision is marked by drastically

619 slowed convergence between India and Eurasia, a change in sedimentation, and the beginning of

620 the prograde path of the UHP metamorphism. The Tethys oceanic lithosphere was pulling the

621 frontal parts of the India margin to great depth, occasionally recording UHP peak conditions at 55-

$62245 \mathrm{Ma}$. The early collision is also recorded in the Tethyan domain by early, mantle-derived

623 magmatism and a long magmatic and metamorphic history in the North Himalayan Domes, where

624 there is a lack of monazite data. Amphibolite facies metamorphics exhumed in these domes are

625 the witnesses of a thickened crust, whereas early plutons represent accreted material during 626 collision.

627 The precursors of the Himalayan Mountain Belt appear ca. 40 Ma. The Himalaya are an 628 intracontinental mountain belt at least 10 m.y. younger, as has been long recognized (e.g., Bird 629 1978; Chemenda et al. 2000).

\section{Acknowledgements}

631 We are thankful to the editors for asking us to contribute and finalize this review and discussion.

632 The ideas discussed here result from many stimulating and informative discussions with many 633 colleagues, in particular Celal Şengör whose enthusiasm is equaled only by the power of his voice.

634 S. Guillot and an anonymous reviewer helped strengthening the text. The French CNRS and the 635 ETH-Zurich supported the authors in their research. 


\section{References}

Ader, T., Avouac, J.-P., Zeng, J.L., Lyon-Caen, H., Bollinger, L., Galetzka, J., Genrich, J., Thomas, M., Chanard, K., Sapkota, S.N., Rajaure, S., Shrestha, P., Ding, L., and Flouzat, M. 2012. Convergence rate across the Nepal Himalaya and interseismic coupling on the Main Himalayan Thrust: Implications for seismic hazard. J. Geophys. Res. 117(B04403): 16 p. doi: 10.1029/2011JB009071.

Aikman, A.B., Harrison, T.M., and Lin, D. 2008. Evidence for Early (>44 Ma) Himalayan Crustal Thickening, Tethyan Himalaya, southeastern Tibet. Earth Planet. Sci. Lett. 274(1): 14-23. doi: https://doi.org/10.1016/j.eps1.2008.06.038.

Aitchison, J.C., Ali, J.R., and Davis, A.M. 2007. When and where did India and Asia collide? J. Geophys. Res. 112(BO5423): 19. doi: 10.1029/2006JB004706.

Aitchison, J.C., Zhu, B.D., Davis, A.M., Liu, J.B., Luo, H., Malpas, J.G., McDermid, I.R.C., Wu, H.Y., Ziabrev, S.V., and Zhou, M.F. 2000. Remnants of a Cretaceous intra-oceanic subduction system within the Yarlung-Zangbo suture (southern Tibet). Earth Planet. Sci. Lett. 183(1-2): 231244.

Ali, J.R., and Aitchinson, J.C. 2005. Greater India. Earth Sci. Rev. 72(3-4): 169-188. doi: 10.1016/j.earscirev.2005.07.005.

Allègre, C.J., Courtillot, V., Tapponnier, P., Hirn, A., Mattauer, M., Coulon, C., Jaeger, J.-J., Achache, J., Schärer, U., Marcoux, J., Burg, J.-P., Girardeau, J., Armijo, R., Gariepy, C., Göpel, C., Li, T., Xiao, X., Chang, C., Li, G., Lin, B., Teng, J., Wang, N., Chen, G., Han, T., Wang, X., Den, W., Sheng, H., Cao, Y., Zhou, J., Qiu, H., Bao, P., Wang, S., Wang, B., Zhou, Y., and Xu, R. 1984. Structure and evolution of the Himalaya-Tibet orogenic belt. Nature 307(5946): 17-22. 
An, W., Hu, X.M., and Garzanti, E. 2017. Sandstone provenance and tectonic evolution of the Xiukang Mélange from Neotethyan subduction to India-Asia collision (Yarlung-Zangbo suture, south Tibet). Gondwana Research 41: 222-234. doi: 10.1016/j.gr.2015.08.010.

An, W., Hu, X.M., Garzanti, E., BouDagher-Fadel, M.K., Wang, J.G., and Sun, G.Y. 2014. Xigaze forearc basin revisited (South Tibet): Provenance changes and origin of the Xigaze Ophiolite. Geol. Soc. Amer. Bull. 126(11/12): 1595-1613. doi: 0.1130/B31020.1.

Anczkiewicz, R., Burg, J.-P., Villa, I.M., and Meier, M. 2000. Late Cretaceous blueschist metamorphism in the Indus Suture Zone, Shangla region, Pakistan Himalaya. Tectonophysics 324(1-2): 111-134.

Aoya, M., Wallis, S.R., Terada, K., Lee, J., Kawakami, T., Wang, Y., and Heizler, M. 2005. Northsouth extension in the Tibetan crust triggered by granite emplacement. Geology 33(11): 853-856. doi: $10.1130 / \mathrm{G} 21806.1$.

Argand, E. 1924. La tectonique de l'Asie. Comptes Rendus du $13^{\text {ème }}$ Congrès géologique international, Bruxelles Fascicule 1: 171-372.

Bard, J.-P. 1983. Metamorphism of an obducted island arc: Example of the Kohistan sequence (Pakistan) in the Himalayan collided range. Earth Planet. Sci. Lett. 65(1): 133-144. doi: 10.1016/0012-821X(83)90195-4.

Beck, R.A., Burbank, D.W., Sercombe, W.J., Khan, A.M., and Lawrence, R.D. 1996. Late Cretaceous ophiolite obduction and Paleocene India-Asia collision in the Westernmost Himalaya. Geodinamica Acta 9(2-3): 114-144. doi: 10.1080/09853111.1996.11105281.

Beloussov, V.V., Belyaevsky, N.A., Borisov, A.A., Volvovsky, B.S., Volkovsky, I.S., Resvoy, D.P., Tal-Virsky, B.B., Khamrabaev, I.K., Kaila, K.L., Narain, H., Marussi, A., and Finetti, J. 
1980. Structure of the lithosphere along the deep seismic sounding profile: Tien Shan-PamirsKarakorum-Himalayas. Tectonophysics 70(3): 193-221. doi: 10.1016/0040-1951(80)90279-6.

Besse, J., and Courtillot, V. 1991. Revised and synthetic apparent wander paths of the African, Eurasian, North American and Indian Plates, and true polar wander since 200 Ma. J. Geophys. Res. 96(B3): 4029-4050.

Besse, J., Courtillot, V., Pozzi, J.-P., Westphal, M., and Zhou, Y.X. 1984. Paleomagnetic estimates of crustal shortening in the Himalayan thrusts and Zangbo suture. Nature 311(5987): 621-626. doi: $10.1038 / 311621 \mathrm{a} 0$.

Bilham, R., Larson, K., and Freymueller, J. 1997. GPS measurements of present-day convergence across the Nepal Himalaya. Nature 386: 61-64. doi: 10.1038/386061a0.

Bird, P. 1978. Initiation of intracontinental subduction in the Himalaya. J. Geophys. Res. 83(B10): 4975-4987. doi: 10.1029/JB083iB10p04975

Bouilhol, P., Jagoutz, O., Hanchar, J.M., and Dudas, F.O. 2013. Dating the India-Eurasia collision through arc magmatic records. Earth Planet. Sci. Lett. 366: 163-175. doi: 10.1016/j.eps1.2013.01.023.

Brune, S., Heine, C., Perez-Gussinye, M., and Sobolev, S.V. 2014. Rift migration explains continental margin asymmetry and crustal hyper-extension. Nature Communications 5(4014). doi: 10.1038/ncomms5014.

Brunel, M. 1986. Ductile thrusting in the Himalayas: shear sense criteria and stretching lineations. Tectonics 5(2): 247-265.

Burchfiel, B.C., Chen, Z.L., Hodges, K.V., Liu, Y.P., Royden, L.H., Deng, C.R., and Xu, J.N. 1992. The South Tibetan Detachment System, Himalayan Orogen: Extension contemporaneous 
with and parallel to shortening in a collisional mountain belt. Spec. Pap. Geol. Soc. Am. 269: 141. doi: 10.1130/SPE269-p1.

Burg, J.-P. 2007. Two orogenic systems and a transform-transfer fault in the Himalayas: evidence and consequences. Earth Science Frontiers 13(4): 27-46.

Burg, J.-P. 2011. The Asia-Kohistan-India Collision: Review and Discussion. In Arc-Continent Collision. Edited by D. Brown and P.D. Ryan. Springer-Verlag, Berlin, Heidelberg. pp. 279-309.

Burg, J.-P., Brunel, M., Gapais, D., Chen, G.M., and Liu, G.H. 1984a. Deformation of leucogranites of the Crystalline Main Central Thrust Sheet in southern Tibet (China). J. Struct. Geol. 6(5): 535-542. doi: 10.1016/0191-8141(84)90063-4.

Burg, J.-P., and Chen, G.M. 1984. Tectonics and structural zonation of southern Tibet, China. Nature 311(5983): 219-223.

Burg, J.-P., Guiraud, M., Chen, G.M., and Li, G.C. 1984b. Himalayan metamorphism and deformations in the North Himalayan Belt (southern Tibet, China). Earth Planet. Sci. Lett. 69: 391400. doi: 10.1016/0012-821X(84)90197-3.

Burg, J.-P., Leyreloup, A., Girardeau, J., and Chen, G.M. 1987. Structure and metamorphism of a tectonically thickened continental crust: the Yalu Tsangpo suture zone (Tibet). Philos. Trans. R. Soc. London A321: 67-86.

Butler, R. 1995. When did India hit Asia? Nature 373: 20-21. doi: 10.1038/373020a0.

Cande, S.C., and Stegman, D.R. 2011. Indian and African plate motions driven by the push force of the Réunion plume head. Nature 475(7354): 47-52. doi: 10.1038/nature10174. 
Capitanio, F.A., Morra, G., Goes, S., Weinberg, R.F., and Moresi, L. 2010. India-Asia convergence driven by the subduction of the Greater Indian continent. Nature Geoscience 3(2): 136-139. doi: 0.1038/NGEO725.

Carosi, R., Montomoli, C., Langone, A., Turina, A., Cesare, B., Iaccarino, S., Fascioli, L., Visonà, D., and Ronchi, A. 2015. Eocene partial melting recorded in peritectic garnets from kyanite-gneiss, Greater Himalayan Sequence, central Nepal. Geological Society, London, Special Publications 412(1): 111-129. doi: 10.1144/SP412.1.

Chemenda, A.I., Burg, J.-P., and Mattauer, M. 2000. Evolutionary model of the Himalaya-Tibet system: geopoem based on new modelling, geological and geophysical data. Earth Planet. Sci. Lett. 174(3-4): 397-409. doi: 10.1016/S0012-821X(99)00277-0

Chen, S.-S., Fan, W.-M., Shi, R.-D., Liu, X.-H., and Zhou, X.-J. 2018. 118-115 Ma magmatism in the Tethyan Himalaya igneous province: Constraints on Early Cretaceous rifting of the northern margin of Greater India. Earth and Planetary Science Letters 491: 21-33. doi: https://doi.org/10.1016/j.eps1.2018.03.034.

Chu, M.-F., Chung, S.-L., Song, B., Liu, D.Y., O'Reilly, S.Y., Pearson, N.J., Ji, J.Q., and Wen, D.J. 2006. Zircon $\mathrm{U}-\mathrm{Pb}$ and $\mathrm{Hf}$ isotope constraints on the Mesozoic tectonics and crustal evolution of southern Tibet. Geology 34(9): 745-748. doi: 10.1130/G22725.1.

Chu, M.F., Chung, S.L., O'Reilly, S.Y., Pearson, N.J., Wu, F.Y., Li, X.H., Liu, D., Ji, J.Q., Chu, C.H., and Lee, H.Y. 2011. India's hidden inputs to Tibetan orogeny revealed by Hf isotopes of Transhimalayan zircons and host rocks. Earth And Planetary Science Letters 307: 479-486.

Chung, S.-L., Chu, M.-F., Zhang, Y.Q., Xie, Y.W., Lo, C.-H., Lee, T.-Y., Lan, C.-Y., Li, X.H., Zhang, Q., and Wang, Y.Z. 2005. Tibetan tectonic evolution inferred from spatial and temporal 
variations in post-collisional magmatism. Earth Sci. Rev. 68(3): 173-196. doi: 10.1016/j.earscirev.2004.05.001.

Clarke, G.L., Bhowmik, S.K., Ireland, T.R., Aitchison, J.C., Chapman, S.L., and Kent, L. 2016. Inverted Oligo-Miocene metamorphism in the Lesser Himalaya Sequence, Arunachal Pradesh, India; age and grade relationships. J. metamorphic Geol. 34(8): 805-820. doi: doi:10.1111/jmg.12202.

Clementz, M., Bajpai, S., Ravikant, V., Thewissen, J.G.M., Saravanan, N., Singh, I.B., and Prasad, V. 2011. Early Eocene warming events and the timing of terrestrial faunal exchange between India and Asia. Geology 39(1): 15-18. doi: 10.1130/G31585.1.

Coleman, M.E., and Hodges, K.V. 1998. Contrasting Oligocene and Miocene thermal histories from the hanging wall and footwall of the South Tibetan detachment in the central Himalaya from 40Ar/39Ar thermochronology, Marsyandi Valley, central Nepal. Tectonics 17(5): 726-740. doi: $10.1029 / 98 \mathrm{TC} 02777$

Condie, K.C. 1997. Plate tectonics and crustal evolution. fourth edition ed. ButterworthHeinemann, Oxford.

Copley, A., Avouac, J.-P., and Royer, J.-Y. 2010. The India-Asia collision and the Cenozoic slowdown of the Indian plate; implications for the forces driving plate motions. J. Geophys. Res. 115(B3): B3410, 3414p. doi: 10.1029/2009JB006634.

Corrie, S.L., and Kohn, M.J. 2011. Metamorphic history of the central Himalaya, Annapurna region, Nepal, and implications for tectonic models. Bulletin 123(9-10): 1863-1879. doi: https://doi.org/10.1130/B30376.1. 
Corrie, S.L., Kohn, M.J., and Vervoort, J.D. 2010. Young eclogite from the Greater Himalayan Sequence, Arun Valley, eastern Nepal: P-T-t path and tectonic implications. Earth Planet. Sci. Lett. 289(3): 406-416. doi: https://doi.org/10.1016/j.eps1.2009.11.029.

Cottle, J.M., Jessup, M.J., Newell, D.L., Horstwood, M.S.A., Noble, S.R., Parrish, R.R., Waters, D.J., and Searle, M.P. 2009. Geochronology of granulitized eclogite from the Ama Drime Massif: Implications for the tectonic evolution of the South Tibetan Himalaya. Tectonics 28. doi: 10.1029/2008TC002256.

Cottle, J.M., Searle, M.P., Jessup, M.J., Crowley, J.L., and Law, R.D. 2015. Rongbuk re-visited: Geochronology of leucogranites in the footwall of the South Tibetan Detachment System, Everest Region, Southern Tibet. Lithos 227: 94-106. doi: https://doi.org/10.1016/j.lithos.2015.03.019.

Coward, M.P., Jan, M.Q., Rex, D., Tarney, J., Thirlwall, M., and Windley, B.F. 1982. Geo-tectonic framework of the Himalaya of N Pakistan. Journal of the Geological Society 139(3): 299-308. doi: 10.1144/gsjgs.139.3.0299.

Cox, A., and Hart, R.B. 1986. Plate tectonics. How it works. Blackwell Scientific Publications, Oxford.

Dai, J.G., Wang, C.S., and Li, Y.L. 2012. Relicts of the Early Cretaceous seamounts in the centralwestern Yarlung Zangbo Suture Zone, southern Tibet. J. Asian. Earth. Sci. 53: 25-37. doi: http://dx.doi.org/10.1016/j.jseaes.2011.12.024.

De La Torre, T.L., Monsalve, G., Sheehan, A.F., Sapkota, S., and Wu, F. 2007. Earthquake processes of the Himalayan collision zone in eastern Nepal and the southern Tibetan Plateau. Geophysical Journal International 171(2): 718-738. doi: 10.1111/j.1365-246X.2007.03537.x. 
de Sigoyer, J., Chavagnac, V., Blichert-Toft, J., Villa, I.M., Luais, B., Guillot, S., Cosca, M., and Mascle, G. 2000. Dating the Indian continental subduction and collisional thickening in the northwest Himalaya: Multichronology of the Tso Morari eclogites. Geology 28(6): 487-490. doi: 10.1130/0091-7613(2000)28<487:DTICSA >2.0.CO;2.

DeCelles, P.G., Kapp, P., Gehrels, G.E., and Ding, L. 2014. Paleocene-Eocene foreland basin evolution in the Himalaya of southern Tibet and Nepal: Implications for the age of initial IndiaAsia collision. Tectonics 33(5): 824-849. doi: 10.1002/2014TC003522.

DeCelles, P.G., Kapp, P., Quade, J., and Gehrels, G.E. 2011. Oligocene-Miocene Kailas basin, southwestern Tibet: Record of postcollisional upper-plate extension in the Indus-Yarlung suture zone. Geol. Soc. Amer. Bull. 123(7-8): 1337-1362. doi: 10.1130/B30258.1.

DeMets, C., Gordon, R.G., and Argus, D.F. 2010. Geologically current plate motions. Geophys. J. Int. 181(1): 1-80. doi: 10.1111/j.1365-246X.2009.04491.x.

Dewey, J.F. 1977. Suture zone complexities: A review. Tectonophysics 40(1-2): 53-67. doi: https://doi.org/10.1016/0040-1951(77)90029-4.

Dewey, J.F., and Bird, J.M. 1970. Mountain belts and the new global tectonics. J. Geophys. Res. 75: $2625-2647$.

Dewey, J.F., and Burke, K. 1973. Tibetan, Variscan and Precambrian basement reactivation: Products of continental collision. J. Geol. 81: 683-692.

Dewey, J.F., Cande, S., and Pitman, W.C.I. 1989. Tectonic evolution of the India/Eurasia Collision Zone. Eclogae geologicae Helvetiae 82(3): 717-734. doi: http://doi.org/10.5169/seals-166399. 
Dewey, J.F., and Kidd, W.S.F. 1974. Continental collisions in the Appalachian-Caledonian Orogenic Belt: Variations related to complete and incomplete suturing. Geology 2(11): 543-546. doi: https://doi.org/10.1130/0091-7613(1974)2<543:CCITAO>2.0.CO;2.

Dewey, J.F., Pitman III, W.C., Ryan, W.B.F., and Bonnin, J. 1973. Plate tectonics and the evolution of the Alpine system. Geol. Soc. Amer. Bull. 84(10): 3137-3180. doi: 10.1130/00167606(1973)84<3137:PTATEO>2.0.CO;2.

Dey, A., Hussain, M.F., and Barman, M.N. 2018. Geochemical characteristics of mafic and ultramafic rocks from the Naga Hills Ophiolite, India: Implications for petrogenesis. Geoscience Frontiers 9(2): 517-529. doi: https://doi.org/10.1016/j.gsf.2017.05.006.

Ding, H., Zhang, Z., Hu, K., Dong, X., Xiang, H., and Mu, H. 2016. P-T-t-D paths of the North Himalayan metamorphic rocks: Implications for the Himalayan orogeny. Tectonophysics $\mathbf{6 8 3}$ : 393-404. doi: https://doi.org/10.1016/j.tecto.2016.06.035.

Einsele, G., Liu, B., Dürr, S., Frisch, W., Liu, G., Luterbacher, H.P., Ratsbacher, L., Ricken, W., Wendt, J., Wetzel, A., Yu, G., and Zheng, H. 1994. The Xigaze forearc basin: evolution and facies architecture (Cretaceous, Tibet). Sediment. Geol. 90(1): 1-32. doi: 10.1016/0037-0738(94)900140.

Ficini, E., Dal Zilio, L., Doglioni, C., and Gerya, T.V. 2017. Horizontal mantle flow controls subduction dynamics. Scientific Reports 7(1): 7 p. doi: 10.1038/s41598-017-06551-y.

Frank, W., Gansser, A., and Trommsdorff, V. 1977. Geological observations in the Ladakh area (Himalayas). A preliminary report. Schweiz. Mineral. Petrogr. Mitt. 57(1): 89-113. 
Freeburn, R., Bouilhol, P., Maunder, B., Magni, V., and van Hunen, J. 2017. Numerical models of the magmatic processes induced by slab breakoff. Earth and Planetary Science Letters 478: 203213. doi: 10.1016/j.eps1.2017.09.008.

Gansser, A. 1964. Geology of the Himalayas. Interscience, London.

Gao, L.E., and Zeng, L.S. 2014. Fluxed melting of metapelite and the formation of Miocene high$\mathrm{CaO}$ two-mica granites in the Malashan gneiss dome, southern Tibet. Geochim. Cosmochim. Acta 130(0): 136-155. doi: 10.1016/j.gca.2014.01.003.

Garzanti, E., Baud, A., and Mascle, G. 1987. Sedimentary record of the northward flight of India and its collision with Eurasia (Ladakh Himalaya, India). Geodinamica Acta 1(4/5): 297-312. doi: 10.1080/09853111.1987.11105147.

Gibbons, A.D., Whittaker, J.M., and Müller, R.D. 2013. The breakup of East Gondwana: Assimilating constraints from Cretaceous ocean basins around India into a best-fit tectonic model. Journal of Geophysical Research: Solid Earth 118(3): 808-822. doi: 10.1002/jgrb.50079.

Groppo, C., Lombardo , B., Rolfo, F., and Pertusati, P. 2007. Clockwise exhumation path of granulitized eclogites from the Ama Drime range (Eastern Himalayas). J. metamorphic Geol. 25: 51-75. doi: 10.1111/j.1525-1314.2006.00678.x

Grujic, D., Warren, C.J., and Wooden, J.L. 2011. Rapid synconvergent exhumation of Mioceneaged lower orogenic crust in the eastern Himalaya. Lithosphere 3(5): 346-366. doi: 10.1130/L154.1.

Guillot, S., Mahéo, G., de Sigoyer, J., Hattori, K.H., and Pêcher, A. 2008. Tethyan and Indian subduction viewed from the Himalayan high- to ultrahigh-pressure metamorphic rocks. Tectonophysics 451(1-4): 225-241. doi: 10.1016/j.tecto.2007.11.059. 
Guillot, S., Replumaz, A., Hattori, K.H., and Strzerzynski, P. 2007. Initial geometry of western Himalaya and ultrahigh-pressure metamorphic evolution. Journal of Asian Earth Sciences 30(3): 557-564. doi: https://doi.org/10.1016/j.jseaes.2007.01.004.

Guo, X., Li, W., Gao, R., Xu, X., Li, H., Huang, X., Ye, Z., Lu, Z., and Klemperer, S.L. 2017. Nonuniform subduction of the Indian crust beneath the Himalayas. Scientific reports 7(1): 12497. doi: 10.1038/s41598-017-12908-0.

Hafkenscheid, E., Wortel, M.J.R., and Spakman, W. 2006. Subduction history of the Tethyan region derived from seismic tomography and tectonic reconstructions. J. Geophys. Res. 111(B08401): 26 p. doi: 10.1029/2005JB003791.

Harris, N.B.W., Caddick, M.J., Kosler, J., Goswami, S., Vance, D., and Tindle, A.G. 2004. The pressure-temperature-time path of migmatites from the Sikkim Himalaya. J. metamorphic Geol. 22: 249-264. doi: 10.1111/j.1525-1314.2004.00511.x.

Harris, N.B.W., Xu, R.H., Lewis, C.L., Hawkesworth, C.J., and Zhang, Y.Q. 1988. Isotope geochemistry of the 1985 Tibet Geotraverse, Lhasa to Golmud. Philos. Trans. R. Soc. London A327: 263-285. doi: 10.1098/rsta.1988.0129.

Harrison, T.M., Grove, M., Lovera, O.M., Catlos, E.J., and D'Andrea, J. 1999. The origin of Himalayan anatexis and inverted metamorphism: Models and constraints J. Asian. Earth. Sci. 17(5-6): 755-772. doi: 10.1016/S1367-9120(99)00018-8.

Hauck, M.L., Nelson, K.D., Brown, L.D., Zhao, W.J., and Ross, A.R. 1998. Crustal structure of the Himalayan orogen at $90^{\circ}$ east longitude from Project INDEPTH deep reflection profiles. Tectonics 17(4): 481-500. 
Hébert, R., Bezard, R., Guilmette, C., Dostal, J., Wang, C.S., and Liu, Z.F. 2012. The IndusYarlung Zangbo ophiolites from Nanga Parbat to Namche Barwa syntaxes, southern Tibet: First synthesis of petrology, geochemistry, and geochronology with incidences on geodynamic reconstructions of Neo-Tethys. Gondwana Research 22(2): 377-397. doi: http://dx.doi.org/10.1016/j.gr.2011.10.013.

Hirn, A., Lépine, J.-C., Jobert, G., Sapin, M., Wittlinger, G., Xu, Z.X., Gao, E.Y., Wang, X.J., Teng, J.W., Xiong, S.B., Pandey, M.R., and Tater, J.M. 1984a. Crustal structure and variability of the Himalayan border of Tibet. Nature 307(5946): 23-25. doi: 10.1038/307023a0

Hirn, A., Nercessian, A., Sapin, M., Jobert, G., Xu, Z.X., Gao, E.Y., Lu, D.Y., and Teng, J.W. 1984b. Lhasa block and bordering sutures- A continuation of a 500-km Moho traverse through Tibet. Nature 307(5946): 25-27. doi: 10.1038/307025a0.

Hodges, K.V. 2000. Tectonics of the Himalaya and southern Tibet from two perspectives. Geol. Soc. Amer. Bull. 112(3): 324-350.

Hodges, K.V., Hubbard, M.S., and Silverberg, D.S. 1988. Metamorphic constraints on the thermal evolution of the central Himalayan Orogen. Philos. Trans. R. Soc. London A326: 257-280.

Honegger, K., Le Fort, P., Mascle, G., and Zimmermann, J.-L. 1989. The blueschists along the Indus Suture Zone in Ladakh, NW Himalaya. J. metamorphic Geol. 7(1): 57-72.

Hu, X.M., Wang, J.G., BouDagher-Fadel, M.K., Garzanti, E., and An, W. 2016. New insights into the timing of the India-Asia collision from the Paleogene Quxia and Jialazi formations of the Xigaze forearc basin, South Tibet. Gondwana Research 32: 76-92. doi: 10.1016/j.gr.2015.02.007. 
Huntington, K.W., Ehlers, T.A., Hodges, K.V., and Whipp, D.M. 2007. Topography, exhumation pathway, age uncertainties, and the interpretation of thermochronometer data. Tectonics 26(4): 23 p. doi: doi:10.1029/2007TC002108.

Jaeger, J.-J., Courtillot, V., and Tapponnier, P. 1989. Paleontological view of the ages of the Deccan Traps, the Cretaceous/Tertiary boundary, and the India-Asia collision. Geology 17(4): 316-319. doi: 10.1130/0091-7613(1989)017<0316:PVOTAO>2.3.CO;2

Jagoutz, O., Bouilhol, P., Schaltegger, U., and Muntener, O. 2018. The isotopic evolution of the Kohistan Ladakh arc from subduction initiation to continent arc collision. In Himalayan tectonics: a modern synthesis. Edited by P.J. Treloar and M.P. Searle. Geological Society of London.

Jagoutz, O., Royden, L., Holt, A.F., and Becker, T.W. 2015. Anomalously fast convergence of India and Eurasia caused by double subduction. Nature Geoscience 8(6): 475.

Ji, W.-Q., Wu, F.-Y., Chung, S.-L., Wang, X.-C., Liu, C.-Z., Li, Q.-L., Liu, Z.-C., Liu, X.-C., and Wang, J.-G. 2016a. Eocene Neo-Tethyan slab breakoff constrained by 45 Ma oceanic island basalt-type magmatism in southern Tibet. Geology 44(4): 283-286.

Ji, W.Q., Wu, F.Y., Chung, S.L., Wang, X.C., Liu, C.Z., Li, Q.L., Liu, Z.C., Liu, X.C., and Wang, J.G. 2016b. Eocene Neo-Tethyan slab breakoff constrained by 45 Ma oceanic island basalt-type magmatism in southern Tibet. Geology 44(4): 283-286. doi: 10.1130/G37612.1.

Ji, W.Q., Wu, F.Y., Liu, C.Z., and Chung, S.L. 2009. Geochronology and petrogenesis of granitic rocks in Gangdese batholith, southern Tibet. Science in China Series D: Earth Sciences 52(9): 1240-1261. doi: 10.1007/s11430-009-0131-y. 
Jian, T., Aitchison, J.C., and Wan, X.Q. 2016. The youngest marine deposits preserved in southern Tibet and disappearance of the Tethyan Ocean. Gondwana Research 32: 64-75. doi: 10.1016/j.gr.2015.01.015.

Jin, X.C., Huang, H., Shi, Y.K., and Zhan, L.P. 2015. Origin of Permian exotic limestone blocks in the Yarlung Zangbo Suture Zone, Southern Tibet, China: With biostratigraphic, sedimentary and regional geological constraints. J. Asian. Earth. Sci. 104: 22-38. doi: http://dx.doi.org/10.1016/j.jseaes.2014.07.036.

Kakar, S.K., Mian, S.B., and Khan, J. 1971. The geology of the Jandul valley, western Dir. Geol. Bull. Univ. Peshawar 6: 54-73.

Kaneko, Y., Katayama, I., Yamamoto, H., Misawa, K., Ishikawa, M., Rehman, H.U., Kausar, A.B., and Shiraishi, K. 2003. Timing of Himalayan ultrahigh-pressure metamorphism: sinking rate and subduction angle of the Indian continental crust beneath Asia. J. metamorphic Geol. 21(6): 589599. doi: 10.1046/j.1525-1314.2003.00466.x.

Kang, Z.Q., Xu, J.F., Wilde, S.A., Feng, Z.H., Chen, J.L., Wang, B.D., Fu, W.C., and Pan, H.B. 2014. Geochronology and geochemistry of the Sangri Group Volcanic Rocks, Southern Lhasa Terrane: Implications for the early subduction history of the Neo-Tethys and Gangdese Magmatic Arc. Lithos 200-201: 157-168. doi: 10.1016/j.lithos.2014.04.019.

Kapur, V.V., Das, D.P., Bajpai, S., and Prasad, G.V.R. 2017. First mammal of Gondwanan lineage in the early Eocene of India. Comptes Rendus Palevol 16(7): 721-737. doi: https://doi.org/10.1016/i.crpv.2017.01.002.

Kearey, P., Klepeis, K.A., and Vine, F.J. 2009. Global tectonics. third ed. Wiley-Blackwell, Oxford. 
Kellett, D.A., Cottle, J.M., and Smit, M. 2014. Eocene deep crust at Ama Drime, Tibet: Early evolution of the Himalayan orogen. Lithosphere 6(4): 220-229. doi: 10.1130/L350.1.

Kellett, D.A., Grujic, D., Coutand, I., Cottle, J., and Mukul, M. 2013. The South Tibetan detachment system facilitates ultra rapid cooling of granulite-facies rocks in Sikkim Himalaya. Tectonics 32(2): 252-270. doi: https://doi.org/10.1111/j.1525-1314.2010.00893.x.

Klootwijk, C.T., Gee, J.S., Peirce, J.W., Smith, G.M., and McFadden, P.L. 1992. An early IndiaAsia contact: Paleomagnetic constraints from Ninetyeast Ridge, ODP Leg 121. Geology 20(5): 395-398. doi: 10.1130/0091-7613(1992)020<0395:AEIACP>2.3.CO;2.

Klootwijk, C.T., Shah, S.K., Sharma, M.L., Gergan, J., and Tirkey, B. 1979. The extent of Greater India, II. Palaeomagnetic data from the Ladakh intrusives at Kargil, northwestern Himalayas. Earth Planet. Sci. Lett. 44(1): 47-64. doi: 10.1016/0012-821X(79)90007-4.

Klootwijk, C.T., Sharma, M.L., Gergan, J., Shah, S.K., and Gupta, B.K. 1986. Rotational overthrusting of the northwestern Himalaya: further palaeomagnetic evidence from the Riasi thrust sheet, Jammu foothills, India. Earth Planet. Sci. Lett. 80(3-4): 375-393. doi: 10.1016/0012821X(86)90119-6.

Kohn, M.J. 2014. Himalayan metamorphism and its tectonic implications. Annual Review of Earth and Planetary Sciences 42(1): 381-419. doi: doi:10.1146/annurev-earth-060313-055005.

Kohn, M.J., Wieland, M.S., Parkinson, C.D., and Upreti, B.N. 2004. Miocene faulting at plate tectonic velocity in the Himalaya of central Nepal. Earth and Planetary Science Letters 228(3): 299-310. doi: https://doi.org/10.1016/j.epsl.2004.10.007. 
Larson, K.P., Cottle, J.M., and Godin, L. 2011. Petrochronologic record of metamorphism and melting in the upper Greater Himalayan sequence, Manaslu-Himal Chuli Himalaya, west-central Nepal. Lithosphere 3(6): 379-392. doi: https://doi.org/10.1130/L149.1.

Laskowski, A.K., Kapp, P., Vervoort, J.D., and Ding, L. 2016. High-pressure Tethyan Himalaya rocks along the India-Asia suture zone in southern Tibet. Lithosphere 8(5): 574-582. doi: 10.1130/L544.1.

Le Fort, P. 1975. Himalayas: The collided range. Present knowledge of the continental arc. Am. J. Sci 275(A): 1-44.

Le Fort, P. 1986. Metamorphism and magmatism during the Himalayan collision. In Collision tectonics. Edited by M.P. Coward and A.C. Ries. Geological Society, London. pp. 159-172.

Lee, H.-Y., Chung, S.-L., Lo, C.-H., Ji, J.Q., Lee, T.-Y., Qian, Q., and Zhang, Q. 2009. Eocene Neotethyan slab breakoff in southern Tibet inferred from the Linzizong volcanic record. Tectonophysics 477(1-2): 20-35. doi: 10.1016/j.tecto.2009.02.031.

Lee, J., Hacker, B., and Wang, Y. 2004. Evolution of North Himalayan gneiss domes: structural and metamorphic studies in Mabja Dome, southern Tibet. J. Struct. Geol. 26(12): 2297-2316. doi: 10.1016/j.jsg.2004.02.013.

Lee, J., Hacker, B.R., Dinklage, W.S., Wang, Y., Gans, P., Calvert, A., Wan, J., Chen, W., Blythe, A.E., and McClelland, W. 2000. Evolution of the Kangmar Dome, southern Tibet: Structural, petrologic, and thermochronologic constraints. Tectonics 19(5): 872-895. doi: https://doi.org/10.1029/1999TC001147.

Leech, M.L., Singh, S., Jain, A.K., Klemperer, S.L., and Manickavasagam, R.M. 2005. The onset of India-Asia continental collision: Early, steep subduction required by the timing of UHP 
metamorphism in the western Himalaya. Earth Planet. Sci. Lett. 234(1-2): 83-97. doi: 10.1016/j.eps1.2005.02.038.

Li, A., and Mashele, B. 2009. Crustal structure in the Pakistan Himalaya from teleseismic receiver functions. G3 10(12): 11 p. doi: doi:10.1029/2009GC002700.

Liao, Q.A., Li, D.W., Lu, L., Yuan, Y.M., and Chu, L.L. 2008. Paleoproterozoic granitic gneisses of the Dinggye and LhagoiKangri areas from the higher and northern Himalaya, Tibet: Geochronology and implications. Science in China Series D: Earth Sciences 51(2): 240-248. doi: 10.1007/s1 1430-008-0002-y.

Liu, G., and Einsele, G. 1994. Sedimentary history of the Tethyan basin in the Tibetan Himalayas. Geol. Rundsch. 83(1): 32-61.

Lombardo , B., Rolfo, F., and McClelland, W.C. 2016. A review of the first eclogites discovered in the Eastern Himalaya. Eur. J. Mineral. 28(6): 1099-1109. doi: 10.1127/ejm/2016/0028-2553.

Magni, V., Allen, M., Van Hunen, J., and Bouilhol, P. 2017. Continental underplating after slab break-off. Earth and Planetary Science Letters 474: 59-67. doi: https://doi.org/10.1016/j.eps1.2017.06.017.

Makovsky, Y., Klemperer, S.L., Ratschbacher, L., and Alsdorf, D. 1999. Midcrustal reflector on INDEPTH wide-angle profiles: An ophiolitic slab beneath the India-Asia suture in southern Tibet? Tectonics 18(5): 793-808. doi: 10.1029/1999tc900022.

Marcoux, J., and Baud, A. 1996. Late Permian to Late Triassic, Tethyan paleoenvironments. Three snapshots: Late Murgabian, Late Anisian, Late Norian. In The ocean basins and margins: The Tethys Ocean. Edited by A.E.M. Nairn and L.-E. Ricou and B. Vrielynck and J. Dercourt. Plenum Press, New York. pp. 153-190. 
Merkouriev, S., and DeMets, C. 2006. Constraints on Indian plate motion since 20 Ma from dense Russian magnetic data: implications for Indian plate dynamics. G3 7(2): 25. doi: 10.1029/2005GC001079.

Mohn, G., Karner, G.D., Manatschal, G., and Johnson, C.A. 2015. Structural and stratigraphic evolution of the Iberia-Newfoundland hyper-extended rifted margin: a quantitative modelling approach. In Sedimentary Basins and Crustal Processes at Continental Margins: From Modern Hyper-extended Margins to Deformed Ancient Analogues. Edited by G.M. Gibson and F. Roure and G. Manatschal. Geological Society, London. pp. 53-89.

Molnar, P., and Gray, D. 1979. Subduction of continental lithosphere: Some constraints and uncertainties. Geology 7(1): 58-62. doi: 10.1130/0091-7613(1979)7<58:SOCLSC >2.0.CO;2.

Molnar, P., and Stock, J.M. 2009. Slowing of India's convergence with Eurasia since 20 Ma and its implications for Tibetan mantle dynamics. Tectonics 28: TC3001. doi: 10.1029/2008TC002271.

Molnar, P., and Tapponnier, P. 1975. Cenozoic tectonics of Asia: Effects of a continental collision. Science 189(4201): 419-426. doi: 0.1126/science.189.4201.419.

Montomoli, C., Carosi, R., and Iaccarino, S. 2015. Tectonometamorphic discontinuities in the Greater Himalayan Sequence: a local or a regional feature? In Tectonics of the Himalaya. Edited by S. Mukherjee and R. Carosi and P.A. van der Beek and B.K. Mukherjee and D.M. Robinson. Geological Society of London. pp. 25-41.

Mottram, C.M., Parrish, R.R., Regis, D., Warren, C.J., Argles, T.W., Harris, N.B.W., and Roberts, N.M.W. 2015. Using U-Th-Pb petrochronology to determine rates of ductile thrusting: Time 
windows into the Main Central Thrust, Sikkim Himalaya. Tectonics 34(7): 1355-1374. doi: doi:10.1002/2014TC003743.

Mu, A.T., Wen, S.H., Wang, Y.K., and Chang, P.K. 1973. Stratigraphy of the Mount Jolmo Lungma region in Southern Tibet, China. Sci. Sinica 16(1): 96-111. doi: 10.1360/ya1973-16-1-96.

Muttoni, G., Kent, D.V., Garzanti, E., Brack, P., Abrahamsen, N., and Gaetani, M. 2003. Early Permian Pangea 'B' to Late Permian Pangea 'A'. Earth and Planetary Science Letters 215(3): 379394. doi: $10.1016 / \mathrm{S} 0012-821 \mathrm{X}(03) 00452-7$.

Najman, Y., Appel, E., BouDagher-Fadel, M.K., Bown, P., Carter, A., Garzanti, E., Godin, L., Han, J.T., Liebke, U., Oliver, G., Parrish, R., and Vezzoli, G. 2010. Timing of India-Asia collision: Geological, biostratigraphic, and palaeomagnetic constraints. Journal of Geophysical Research: Solid Earth 115(B12): n/a-n/a. doi: 10.1029/2010JB007673.

Nelson, K.D., Wenjin, Z., Brown, L.D., Kuo, J., Jinkai, C., Xianwen, L., Klemperer, S.L., Makovsky, Y., Meissner, R., Mechie, J., Kind, R., Wenzel, F., Ni, J., Nabelek, J., Chen, L., Handing, T., Wenbo, W., Jones, A.G., Booker, J., Unsworth, M., Kidd, W.S.F., Hauck, M., Alsdorf, D., Ross, A., Cogan, M., Changde, W., Sandvol, E., and Edwards, M. 1996. Partially molten middle crust beneath southern Tibet: Synthesis of project INDEPTH results. Science 274(5293): 1684-1688. doi: 10.1126/science.274.5293.1684.

Oliver, G.J.H., Johnson, M.R.W., and Fallick, A.E. 1995. Age of metamorphism in the Lesser Himalaya and the Main Central Thrust zone, Garhwal India: results of illite crystallinity, ${ }^{40} \mathrm{Ar}-{ }^{39} \mathrm{Ar}$ fusion and K-Ar studies. Geol. Mag. 132(2): 139-149. doi: 10.1017/S0016756800011717.

Park, R.G. 1993. Geological structures and moving plates. 2nd ed. Chapman \& Hall, Glasgow. 
Parrish, R., and Hodges, K.V. 1996. Isotopic constraints on the age and provenance of the Lesser and Greater Himalayan sequences, Nepalese Himalaya. Geol. Soc. Amer. Bull. 108(7): 904-911. doi: 10.1130/0016-7606(1996)108<0904:ICOTAA>2.3.CO;2.

Parrish, R.R. 1990. U-Pb dating of monazite and its application to geological problems. Can. J. Earth Sci. 27(11): 1431-1450. doi: 10.1139/e90-152.

Patiño Douce, A.E., and Harris, N. 1998. Experimental Constraints on Himalayan Anatexis. J. Petrol. 39(4): 689-710. doi: 10.1093/petroj/39.4.689.

Patriat, P., and Achache, J. 1984. India-Eurasia collision chronology has implications for crustal shortening and driving mechanism of plates. Nature 311(5987): 615-621. doi: 10.1038/311615a0.

Pêcher, A. 1989. The metamorphism in the Central Himalaya. J. metamorphic Geol. 7(1): 31-41. doi: 10.1111/j.1525-1314.1989.tb00573.x.

Petterson, M.G., and Windley, B.F. 1985. Rb-Sr dating of the Kohistan arc-batholith in the TransHimalaya of north Pakistan, and tectonic implications. Earth Planet. Sci. Lett. 74(1): 45-57. doi: 10.1016/0012-821X(85)90165-7.

Pyle, J.M., and Spear, F.S. 2003. Four generations of accessory-phase growth in low-pressure migmatites from SW New Hampshire. Am. Mineral. 88(2-3): 338-351. doi: 10.2138/am-2003-2311.

Ravikant, V., Wu, F.Y., and Ji, W.Q. 2009. Zircon U-Pb and Hf isotopic constraints on petrogenesis of the Cretaceous-Tertiary granites in eastern Karakoram and Ladakh, India. Lithos 110(1-4): 153-166. doi: 10.1016/j.lithos.2008.12.013. 
Regis, D., Warren, C.J., Young, D., and Roberts, N.M. 2014. Tectono-metamorphic evolution of the Jomolhari massif: Variations in timing of syn-collisional metamorphism across western Bhutan. Lithos 190: 449-466. doi: https://doi.org/10.1016/j.lithos.2014.01.001.

Replumaz, A., Negredo, A.M., Villaseñor, A., and Guillot, S. 2010. Indian continental subduction and slab break-off during Tertiary collision. Terr. Nova 22(4): 290-296. doi: 10.1111/j.13653121.2010.00945.x.

Ricou, L.-E. 1994. Tethys reconstructed: plates, continental fragments and their boundaries since 260 Ma from Central America to South-eastern Asia. Geodinamica Acta 7(4): 169-218. doi: 10.1080/09853111.1994.11105266.

Rolland, Y., Pêcher, A., and Picard, C. 2000. Middle Cretaceous back-arc formation and arc evolution along the Asian margin: the Shyok Suture Zone in northern Ladakh (NW Himalaya). Tectonophysics 325: 145-173.

Rowley, D.B. 1996. Age of initiation of collision between India and Asia: A review of stratigraphic data. Earth Planet. Sci. Lett. 145(1-4): 1-13. doi: 10.1016/S0012-821X(96)00201-4.

Rubatto, D., Chakraborty, S., and Dasgupta, S. 2013. Timescales of crustal melting in the Higher Himalayan Crystallines (Sikkim, Eastern Himalaya) inferred from trace element-constrained monazite and zircon chronology. Contributions to Mineralogy and Petrology 165(2): 349-372.

Savostin, L.A., Sibuet, J.-C., Zonenshain, L.P., Le Pichon, X., and Roulet, M.-J. 1986. Kinematic evolution of the Tethys Belt from the Atlantic Ocean to the Pamirs since the Triassic. Tectonophysics 123(1-4): 1-35. doi: 10.1016/0040-1951(86)90192-7. 
Schärer, U., Xu, R.-H., and Allègre, C.J. 1986. U-(Th)-Pb systematics and ages of Himalayan leucogranites, South Tibet. Earth Planet. Sci. Lett. 77(1): 35-48. doi: 10.1016/0012$821 X(86) 90130-5$.

Schellart, W.P. 2004. Quantifying the net slab pull force as a driving mechanism for plate tectonics. Geophys. Res. Lett. 31(7): L07611 - 07615p. doi: 10.1029/2004GL019528.

Schettino, A., and Scotese, C.R. 2005. Apparent polar wander paths for the major continents (200 Ma to the present day): a palaeomagnetic reference frame for global plate tectonic reconstructions. Geophysical Journal International 163(2): 727-759. doi: 10.1111/j.1365-246X.2005.02638.x.

Schulte-Pelkum, V., Monsalve, G., Sheehan, A., Pandey, M.R., Sapkota, S., Bilham, R., and Wu, F. 2005. Imaging the Indian subcontinent beneath the Himalaya. Nature 435(7046): 1222-1225. doi: $10.1038 /$ nature 03678 .

Searle, M.P., Cooper, D.J.W., Rex, A.J., and Colchen, M. 1988. Collision tectonics of the LadakhZanskar Himalaya. Philosophical Transactions of the Royal Society of London A326: 117-150. doi: $10.1098 /$ rsta. 1988.0082

Searle, M.P., Parrish, R.R., Thow, A.V., Noble, S.R., Phillips, R.J., and Waters, D.J. 2010. Anatomy, age and evolution of a collisional mountain belt: the Baltoro granite batholith and Karakoram Metamorphic Complex, Pakistani Karakoram. J. Geol. Soc. London 167(1): 183-202. doi: 10.1144/0016-76492009-043.

Seeber, L., Armbruster, J.G., and Quittmeyer, R.C. 1981. Seismicity and continental subduction in the Himalayan arc. In Zagros - Hindu Kush - Himalaya, Geodynamic evolution. Edited by H. Gupta and F. Delany. American Geophysical Union Geodynamics series. pp. 215-242. 
Şengör, A.M.C. 1976. Collision of irregular continental margins: Implications for foreland deformation of Alpine-type orogens. Geology 4(12): 779-782. doi: https://doi.org/10.1130/00917613(1976)4<779:COICMI>2.0.CO;2.

Şengör, A.M.C., Natal'in, B.A., Sunal, G., and van der Voo, R. 2018. The Tectonics of the Altaids: Crustal Growth During the Construction of the Continental Lithosphere of Central Asia Between $\sim 750$ and $\sim 130$ Ma Ago. Annual Review of Earth and Planetary Sciences 46(1): 439-494. doi: 10.1146/annurev-earth-060313-054826.

Singh, S. 2018. Protracted zircon growth in migmatites and In situ melt of Higher Himalayan Crystallines: $\mathrm{U}-\mathrm{Pb}$ ages from Bhagirathi valley, NW Himalaya, India. Geoscience Frontiers. doi: 10.1016/j.gsf.2017.12.014.

Smith, H.A., Chamberlain, C.P., and Zeitler, P.K. 1994. Timing and duration of Himalayan metamorphism within the Indian plate, Northwest Himalaya, Pakistan. J. Geol. 102(5): 493-508. doi: $10.1086 / 629694$.

Stampfli, G., and Borel, G.D. 2002. A plate tectonic model for the Paleozoic and Mesozoic constrained by dynamic plate boundaries and restored synthetic oceanic isochrons. Earth Planet. Sci. Lett. 196(1-2): 17-33. doi: 10.1016/S0012-821X(01)00588-X.

Stampfli, G., Marcoux, J., and Baud, A. 1991. Tethyan margins in space and time. Palaeogeogr. Palaeoclimatol. Palaeoecol. 87(1-4): 373-409. doi: 10.1016/0031-0182(91)90142-E.

Sternai, P., Avouac, J.-P., Jolivet, L., Faccenna, C., Gerya, T.V., Becker, T.W., and Menant, A. 2016. On the influence of the asthenospheric flow on the tectonics and topography at a collisionsubduction transition zones: Comparison with the eastern Tibetan margin. Journal of Geodynamics 100: 184-197. doi: 10.1016/j.jog.2016.02.009. 
Tapponnier, P., Peltzer, G., Le Dain, A.Y., Armijo, R., and Cobbold, P. 1982. Propagating extrusion tectonics in Asia: New insights from simple experiments with plasticine. Geology 10(12): 611-616. doi: 10.1130/0091-7613(1982)10<611:PETIAN>2.0.CO;2.

Thakur, V.C., and Misra, D.K. 1984. Tectonic framework of the Indus and Shyok suture zones in eastern Ladakh, northwest Himalaya. Tectonophysics 101: 207-220.

Torsvik, T.H., and Cocks, L.R.M. 2017. Earth history and palaeogeography. Cambridge University Press, Cambridge.

Torsvik, T.H., Tucker, R.D., Ashwal, L.D., Carter, L.M., Jamtveit, B., Vidyadharan, K.T., and Venkataramana, P. 2000. Late Cretaceous India-Madagascar fit and timing of break-up related magmatism. Terra Nova 12(5): 220-224. doi: 10.1046/j.1365-3121.2000.00300.x.

Van der Voo, R., Spakman, W., and Bijwaard, H. 1999. Tethyan subducted slabs under India. Earth Planet. Sci. Lett. 171(1): 7-20. doi: 10.1016/S0012-821X(99)00131-4.

van Hinsbergen, D.J.J., Lippert, P.C., Dupont-Nivet, G., McQuarrie, N., Doubrovine, P.V., Spakman, W., and Torsvik, T.H. 2012. Greater India Basin hypothesis and a two-stage Cenozoic collision between India and Asia. Proceedings of the National Academy of Sciences 109(20): 7659-7664. doi: 10.1073/pnas.1117262109.

van Hinsbergen, D.J.J., Steinberger, B., Doubrovine, P.V., and Gassmöller, R. 2011. Acceleration and deceleration of India-Asia convergence since the Cretaceous: Roles of mantle plumes and continental collision. J. Geophys. Res. 116(B6): B06101, 06120p. doi: 10.1029/2010JB008051.

van Hunen, J., and Allen, M.B. 2011. Continental collision and slab break-off: A comparison of 3-D numerical models with observations. Earth And Planetary Science Letters 302(1-2): 27-37. doi: http://dx.doi.org/10.1016/j.eps1.2010.11.035. 
Verma, R.K., and Prasad, K.A.V.L. 2009. Analysis of gravity fields in the northwestern Himalayas and Kohistan region using deep seismic sounding data. Geophysical Journal International 91(3): 869-889. doi: 10.1111/j.1365-246X.1987.tb01672.x.

von Huene, R., and Scholl, D.W. 1991. Observations at convergent margins concerning sediment subduction, subduction erosion, and the growth of continental crust. Reviews of Geophysics 29(3): 279-316. doi: 10.1029/91RG00969.

Webb, A.A.G., Guo, H.C., Clift, P.D., Husson, L., Müller, T., Costantino, D., Yin, A., Xu, Z.Q., Cao, H., and Wang, Q. 2017. The Himalaya in 3D: Slab dynamics controlled mountain building and monsoon intensification. Lithosphere 9(4): 637-651. doi: 10.1130/L636.1.

Weinberg, R.F. 2016. Himalayan leucogranites and migmatites: nature, timing and duration of anatexis. J. metamorphic Geol. 34(8): 821-843. doi: doi:10.1111/jmg.12204.

Wen, D.-R., Liu, D.Y., Chung, S.-L., Chu, M.-F., Ji, J.Q., Zhang, Q., Song, B., Lee, T.-Y., Yeh, M.-W., and Lo, C.H. 2008. Zircon SHRIMP U-Pb ages of the Gangdese Batholith and implications for Neotethyan subduction in southern Tibet. Chem. Geol. 252(3-4): 191-201. doi: 10.1016/j.chemgeo.2008.03.003.

White, L.T., and Lister, G.S. 2012. The collision of India with Asia. J. Geodynamics 56-57: 7-17. doi: 10.1016/j.jog.2011.06.006.

Whittington, A., Foster, G., Harris, N., Vance, D., and Ayres, M. 1999. Lithostratigraphic correlations in the western Himalaya - An isotopic approach. Geology 27(7): 585-588. doi: 10.1130/0091-7613(1999)027<0585:LCITWH>2.3.CO;2.

Wilke, F.D.H., O'Brien, P.J., Gerdes, A., Timmerman, M.J., Sudo, M., and Khan, M.A. 2001. The multistage exhumation history of the Kaghan Valley UHP series, NW Himalaya, Pakistan from 
$\mathrm{U}-\mathrm{Pb}$ and ${ }^{40} \mathrm{Ar} /{ }^{39} \mathrm{Ar}$ ages. Eur. J. Mineral. 22(5): 703-719. doi: 10.1127/0935-1221/2010/00222051.

Xu, W.-C., Zhang, H.-F., Guo, L., and Yuan, H.-L. 2010. Miocene high Sr/Y magmatism, south Tibet: Product of partial melting of subducted Indian continental crust and its tectonic implication. Lithos 114(3): 293-306. doi: https://doi.org/10.1016/j.lithos.2009.09.005.

Yin, A. 2006. Cenozoic tectonic evolution of the Himalayan orogen as constrained by along-strike variation of structural geometry, exhumation history, and foreland sedimentation. Earth Sci. Rev. 76: 1-131. doi: 10.1016/j.earscirev.2005.05.004.

Yin, A., and Harrison, T.M. 2000. Geologic evolution of the Himalayan-Tibetan orogen. Ann. Rev. Earth Planet. Sci. 28: 211-280. doi: 10.1146/annurev.earth.28.1.211.

Zahirovic, S., Müller, R.D., Seton, M., Flament, N., Gurnis, M., and Whittaker, J. 2012. Insights on the kinematics of the India-Eurasia collision from global geodynamic models

2011GC0038831984. Geochemistry Geophysics Geosystems 13(4): Q04W11, 25p. doi: 10.1029/2011GC003883.

Zeng, L.S., Gao, L.E., Xie, K.J., and Jing, L.Z. 2011. Mid-Eocene high Sr/Y granites in the Northern Himalayan Gneiss Domes: Melting thickened lower continental crust. Earth Planet. Sci. Lett. 303(3-4): 251-266. doi: 10.1016/j.eps1.2011.01.005.

Zhang, J.J., Santosh, M., Wang, X.X., Guo, L., Yang, X.G., and Zhang, B. 2012. Tectonics of the northern Himalaya since the India-Asia collision. Gondwana Research 21(4): 939-960. doi: 10.1016/j.gr.2011.11.004. 
Zhang, L.-Y., Ducea, M.N., Ding, L., Pullen, A., Kapp, P., and Hoffman, D. 2014. Southern Tibetan Oligocene-Miocene adakites: A record of Indian slab tearing. Lithos 210-211: 209-223. doi: https://doi.org/10.1016/j.lithos.2014.09.029.

Zhu, D.-C., Chung, S.-L., Mo, X.-X., Zhao, Z.-D., Niu, Y., Song, B., and Yang, Y.-H. 2009. The $132 \mathrm{Ma}$ Comei-Bunbury large igneous province: Remnants identified in present-day southeastern Tibet and southwestern Australia. Geology 37(7): 583-586.

Zhu, D.-C., Zhao, Z.-D., Niu, Y.L., Mo, X.-X., Chung, S.-L., Hou, Z.-Q., Wang, L.-Q., and Wu, F.-Y. 2011. The Lhasa Terrane: Record of a microcontinent and its histories of drift and growth. Earth Planet. Sci. Lett. 301(1-2): 241-255. doi: 10.1016/j.eps1.2010.11.005.

Zhuang, G.S., Najman, Y., Guillot, S., Roddaz, M., Antoine, P.-O., Métais, G., .ndrew, Marivaux, L., and Solangi, S.H. 2015. Constraints on the collision and the pre-collision tectonic configuration between India and Asia from detrital geochronology, thermochronology, and geochemistry studies in the lower Indus basin, Pakistan. Earth Planet. Sci. Lett. 432: 363-373. doi: 10.1016/j.eps1.2015.10.026. 


\section{Figure captions}

Fig. 1: Sketch map of the South Tibet-Himalayan orogenic belt with reference to the lithological and tectonic zones discussed in the text, adapted from several reviews, some referenced in the text.

Fig. 2: Simplified sections (located on Fig. 1) showing interpretation of crustal structures across the South Tibet-Himalayan orogenic belt. Magmatic ages discussed in text and reported in figures 3 and 4. Same colours as in figure 1. A: Tsangpo Suture - Central Himalaya section; deep reflectors (Moho and dashed thrust (?) lines from Hirn et al. (1984a), Hirn et al. (1984b), Nelson et al. (1996), Hauck et al. (1998) and Schulte-Pelkum et al. (2005). Deep within mantle seismogenic zone from De La Torre et al. (2007). B: Western Himalaya: Structural variations and Moho depth after Verma and Prasad (2009) and Li and Mashele (2009); Moho offset, crustal detachment and faults after Seeber et al. (1981), after Beloussov et al. (1980) beneath North-Kohistan and Karakoram.

Fig. 3: Histogram of crystallization ages of plutonic rocks defined by zircons. $n=$ number of data. Several vaguely located samples did not permit minimize sampling bias. References used for this compilation are given in electronic supplement.

Fig. 4: Tectonic reconstruction of the India-Asia convergence system in late Cretaceous times. Options chosen are that (1) the main Indian units are inherited from extensional structures of the passive margin, including the MCT, which may have reactivated the breakaway fault 
zone, and (2) intra-oceanic arcs existed all along the orogenic zone and were subducted beneath the Eurasian margin. Discussion in text.

Fig. 5: Histogram of ${ }^{206} \mathrm{~Pb} /{ }^{238} \mathrm{U}$ zircon data for the North Himalaya granitoids. References in Supplementary material. Abbreviations as in text and figure 3.

Fig. 6: Simplified geologic and metamorphic cross section through the Himalaya of Central Nepal after Le Fort (1986). Ages from Corrie and Kohn (2011) and Kohn et al. (2004), orange = prograde monazite and blue $=$ retrograde monazite. Intrusion age of Manaslu leucogranite from Harrison et al. (1999). Same colours as in Figure 1; section slightly to the west of, and parallel to the High Himalaya part of section A, Fig. 2.

Fig. 7: Histogram of ${ }^{206} \mathrm{~Pb} /{ }^{238} \mathrm{U}$ monazite and zircon data are from the Everest region (Larson et al. 2011), Annapurna (Corrie and Kohn 2011) and Bhutan (Kellett et al. 2013; Regis et al. 2014; Rubatto et al. 2013). Other references in supplementary material. 


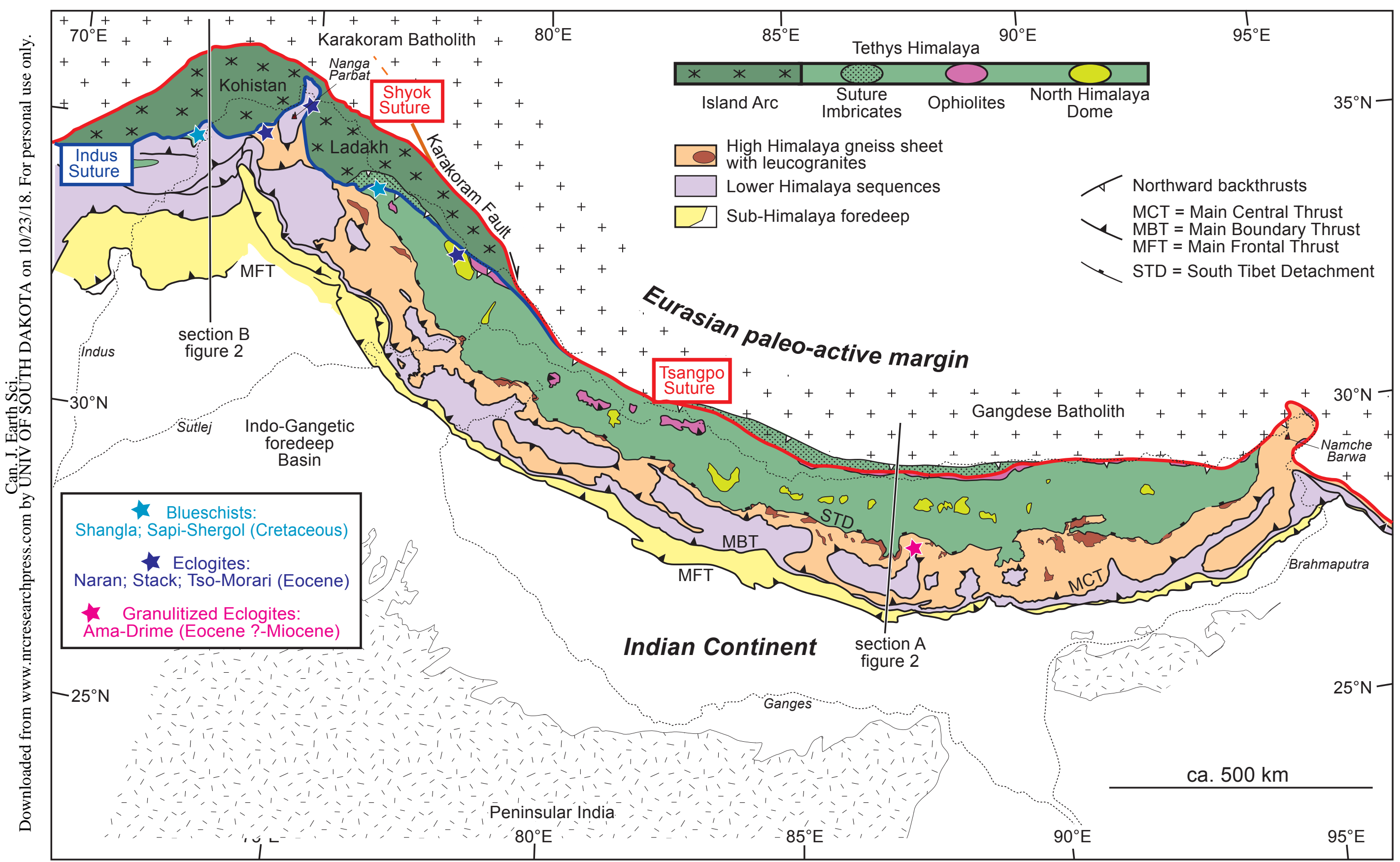

Fig. 1: Sketch map of the South-Tibet--Himalayan orogenic belt with reference to the lithological and tectonic zones discussed in the text, adapted from several reviews, some referenced in the text. 

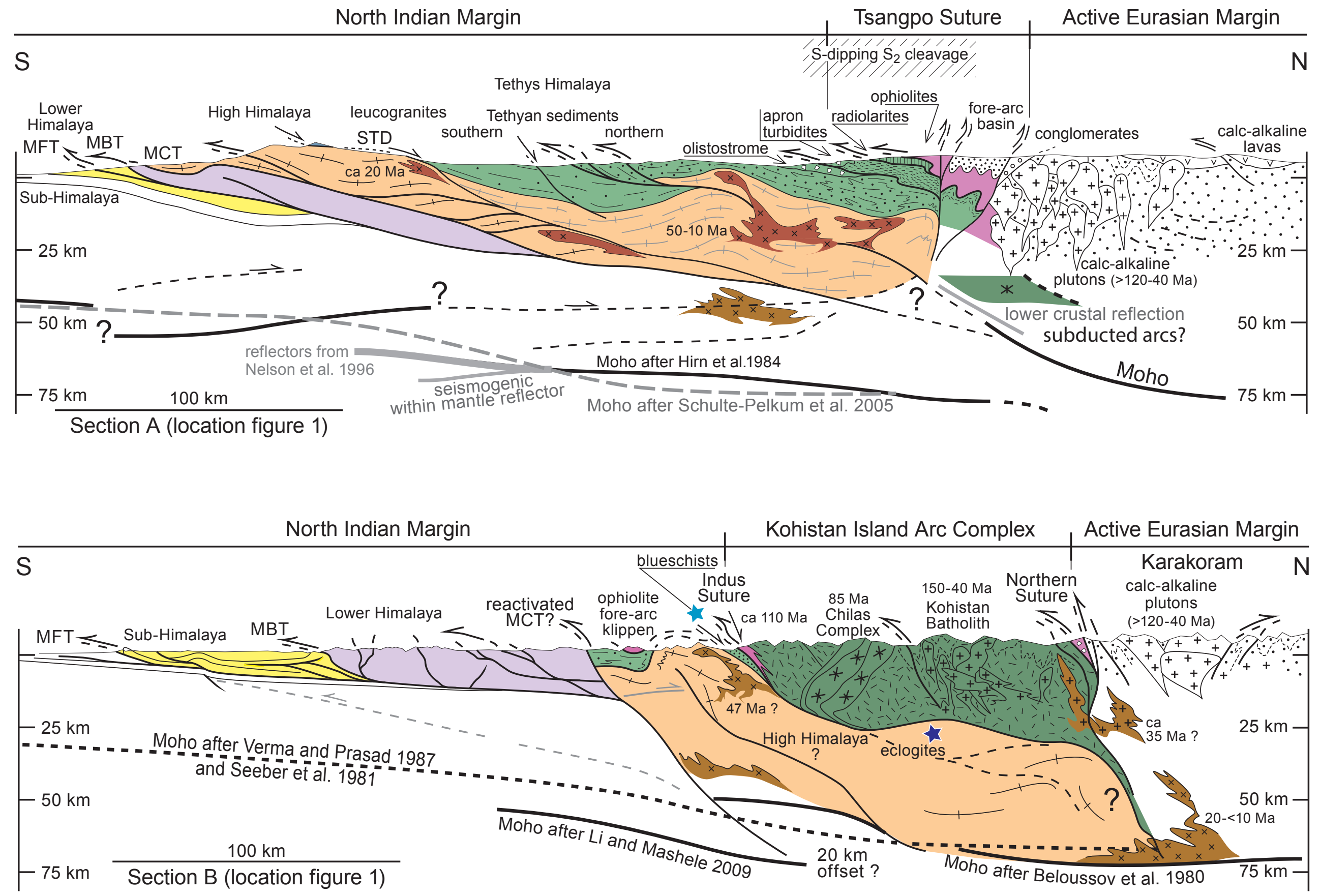

Fig. 2: Simplified sections (located on Fig. 1) showing interpretation of crustal structures across the South-Tibet--Himalayan orogenic belt. Magmatic ages discussed in text and reported in figures 3 and 4. Same colours as in figure 1. A: Tsangpo Suture - Central Himalaya section; deep reflectors (Moho and dashed thrust (?) lines from (Hirn et al. 1984a; Hirn et al. 1984b), (Nelson et al. 1996), (Hauck et al. 1998) and (Schulte-Pelkum et al. 2005). Deep within mantle seismogenic zone from (De La Torre et al. 2007). B: Western Himalaya: Structural variations and Moho depth after (Verma and Prasad 2009) and (Li and Mashele 2009); Moho offset, crustal detachment and faults after (Seeber et al. 1981), after (Beloussov et al. 1980) beneath North-Kohistan and Karakoram. 


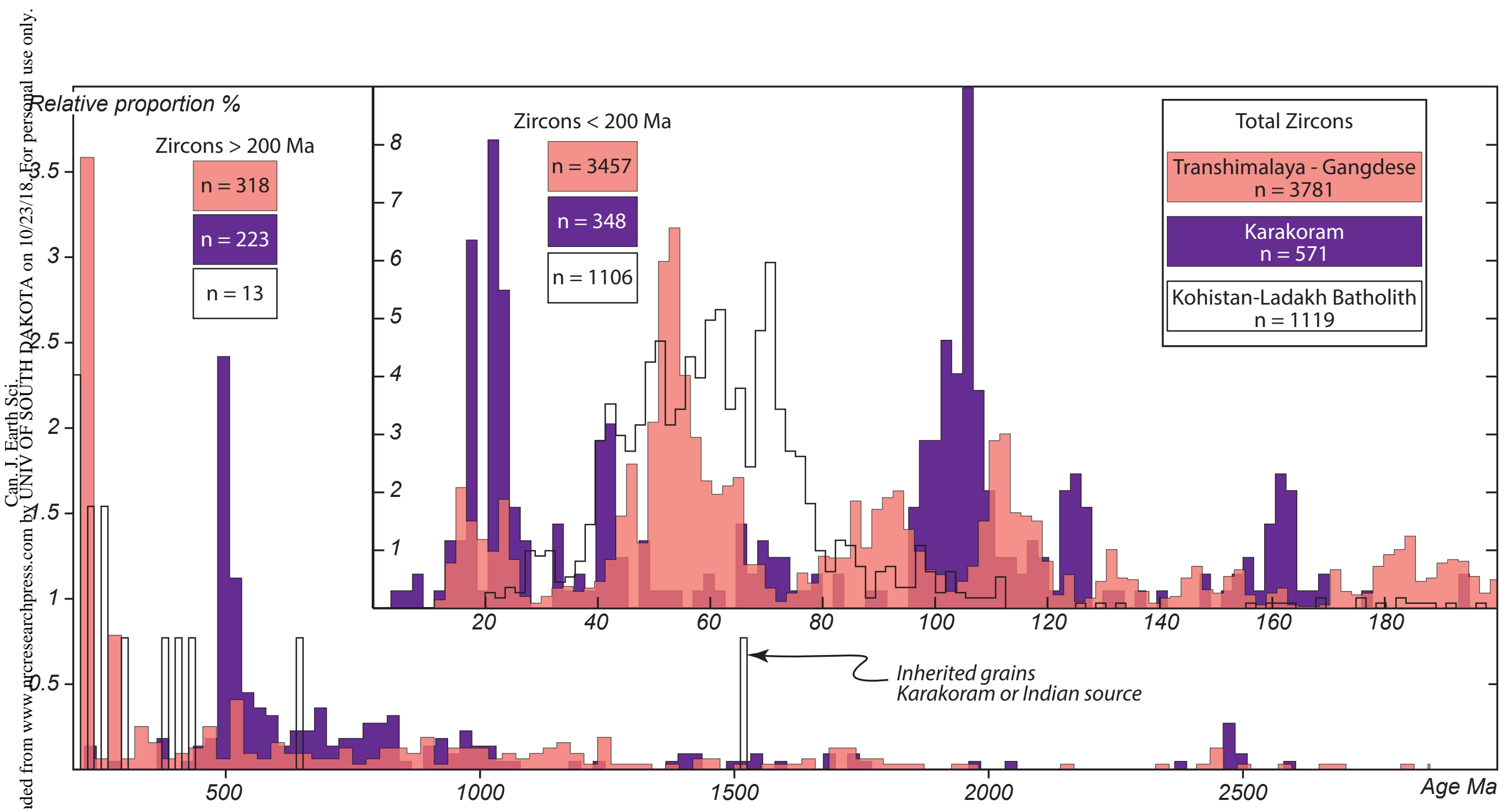

Fig. 3: Histogram of crystallization ages of plutonic rocks defined by zircons. $n=$ number of data. Several vaguely located samples did not permit minimize sampling bias. References used for this compilation are given in electronic supplement. 


\section{$\mathrm{S}$ $75 \mathrm{Ma}$}

wide passive continental margin of India ("Greater India") future
future $\quad$ North-Himalayan $\begin{array}{ccc}\text { future } & \begin{array}{c}\text { North-Himalayan } \\ \text { domes? }\end{array} & \begin{array}{c}\text { future } \\ \text { UHP rocks? }\end{array}\end{array}$

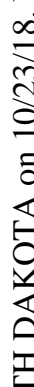
oceanic
lithosphere

\section{Tethys Ocean}

50 Ma collision accretionary wedge
with $90 \mathrm{Ma}$ blueschists

40 Ma collision

active continental margin

of Eurasia lavas intra-oceanic

fore arc (Xigaze)

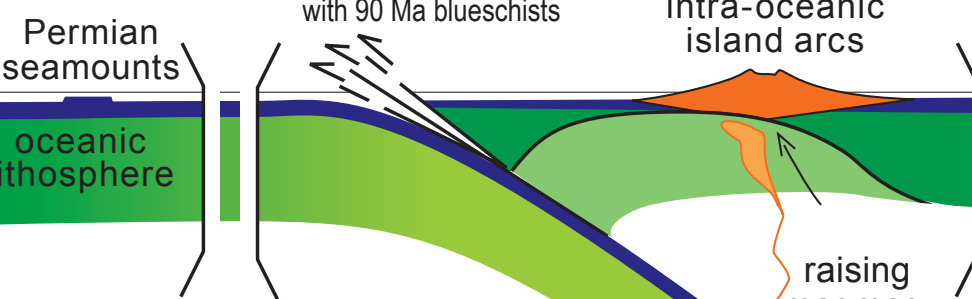

raising

(1)
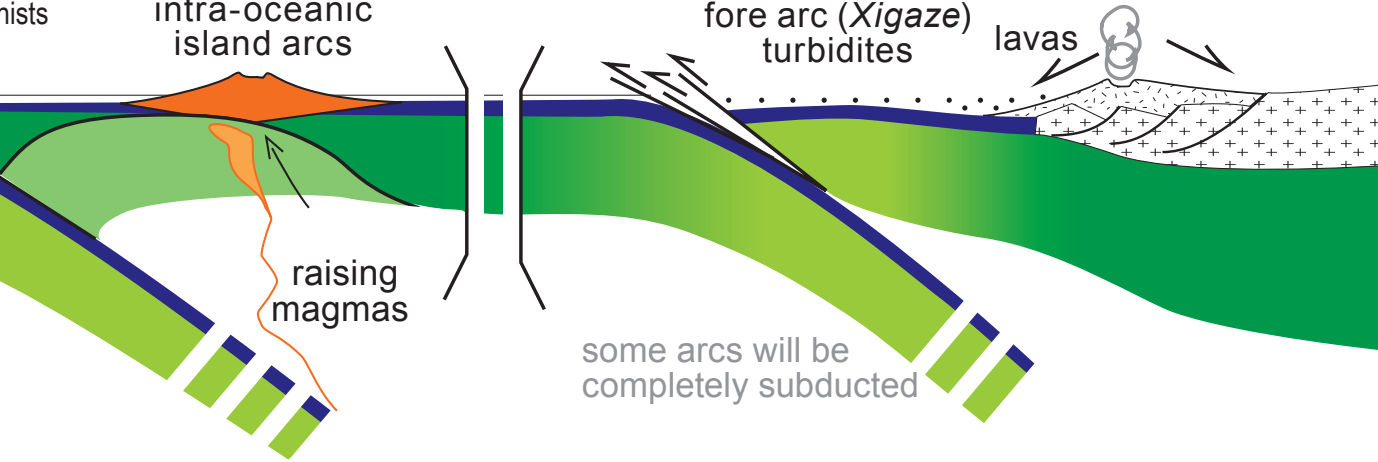

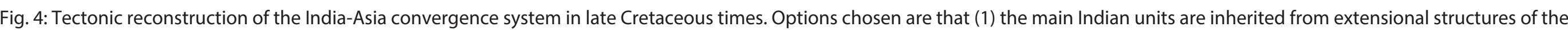

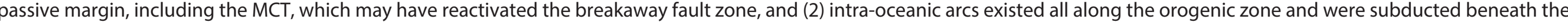
Eurasian margin. Discussion in text. 


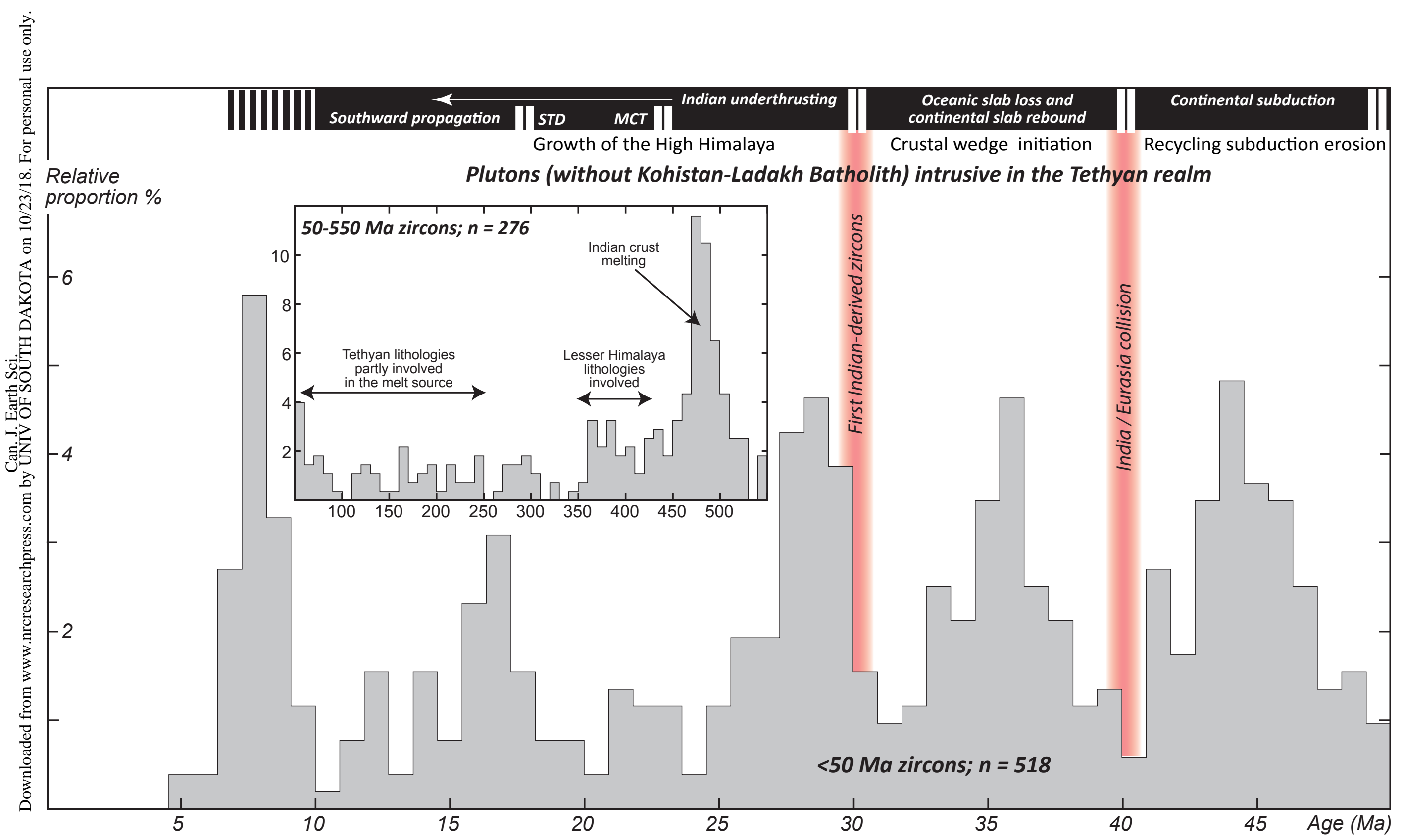

Fig. 5: Histogram of $206 \mathrm{~Pb} / 238 \mathrm{U}$ zircon data for the North Himalaya granitoids. References in Supplementary material. Abbreviations as in text and figure 3. 


\section{Page 63 of 64}

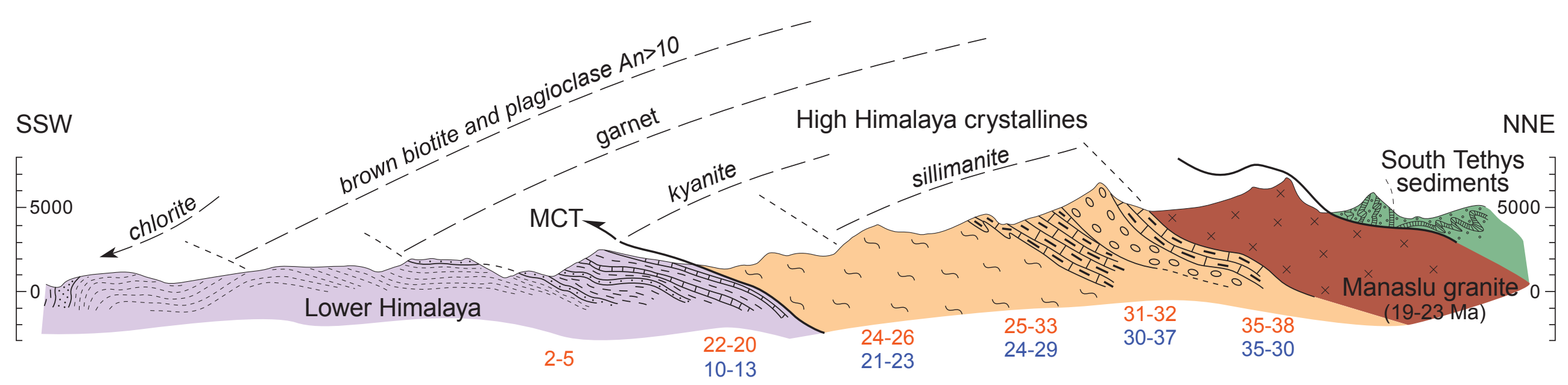

Fig. 6: Simplified geologic and metamorphic cross section through the Himalaya of Central Nepal after (Le Fort 1986). Ages from (Corrie and Kohn 2011) and (Kohn et al. 2004), orange = prograde monazite and blue = retrograde monazite. Intrusion age of Manaslu leucogranite from (Harrison et al. 1999). Same colours as in Figure 1; section slightly to the west of, and parallel to the High Himalaya part of section A, Fig. 2. 


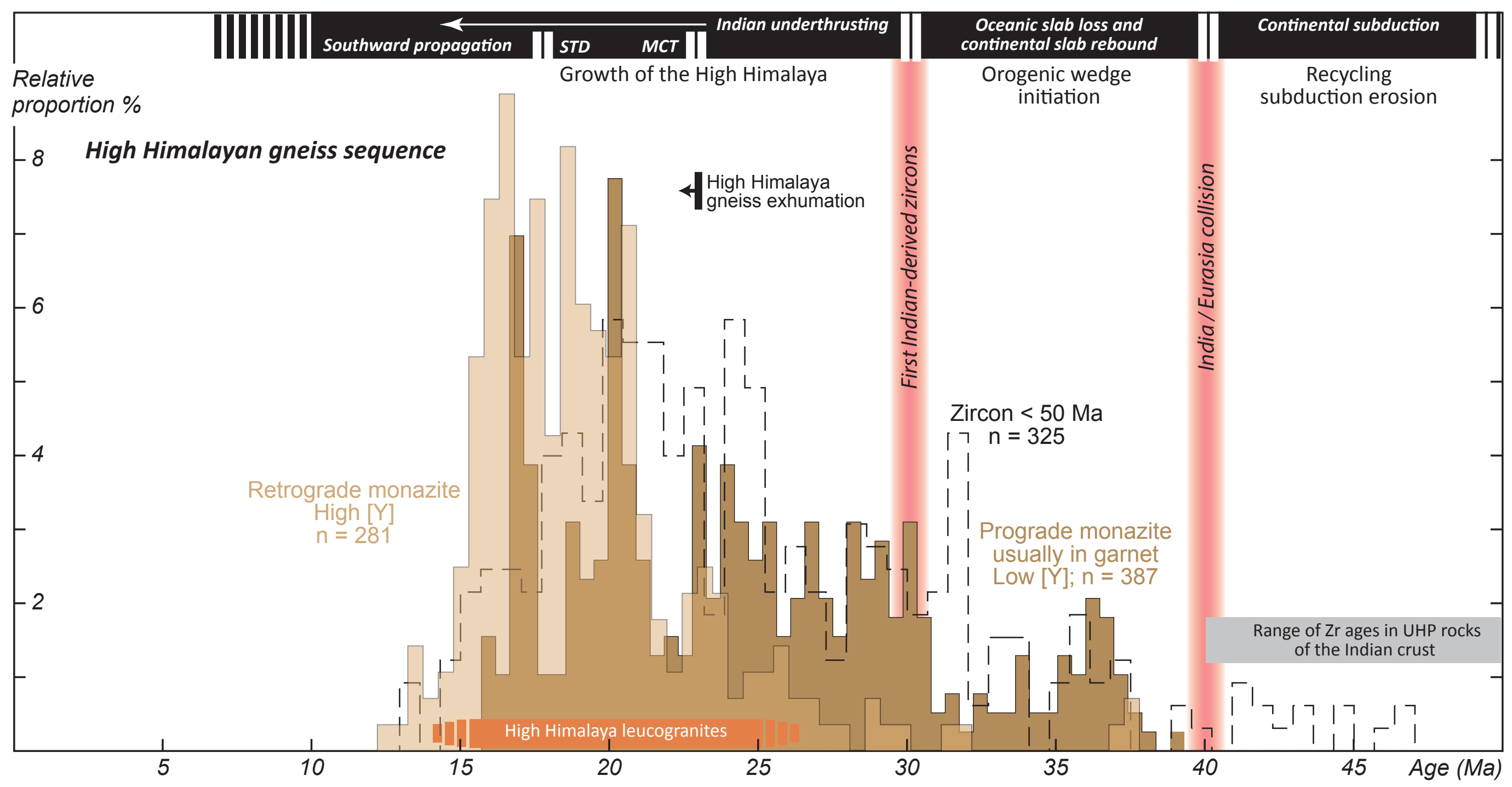

Fig. 7: Histogram of 206Pb/238U monazite and zircon data are from the Everest region (Larson et al. 2011), Annapurna (Corrie and Kohn 2011) and Bhutan (Kellett et al. 2013; Regis et al. 2014) and (Rubatto et al. 2013). Other references in supplementary material 